\title{
A CONTAGEM DOS PRAZOS PROCESSUAIS DE ACORDO COM O NOVO CÓDIGO DE PROCESSO CIVIL
}

\section{THE COUNT OF PROCEDURAL DEADLINES IN ACCORDANCE WITH THE NEW CODE OF CIVIL PROCEDURE}

\author{
Matheus de Mello Eufrázio ${ }^{1}$ \\ Anelise Crippa ${ }^{2}$
}

RESUMO: Propõe-se nesta pesquisa verificar as alterações trazidas pelo Novo Código de Processo Civil no que concerne à contagem dos prazos processuais, suas consequências e como a regra está sendo interpretada, utilizando-se, para tanto, de busca doutrinária e jurisprudencial. Após a realização deste trabalho, restou notável a existência de consideráveis divergências entre os Tribunais quanto à contagem dos prazos processuais, demonstrando, portanto, ainda não existir uma aceitação geral quanto à inovação abarcada pelo Carta Processual em vigor.

Palavras-chave: Prazos processuais. Dias úteis. Código de Processo Civil. Contagem.

ABSTRACT: It is proposed in this research to verify the changes brought by the New Code of Civil Procedure in the scope of the counting of procedural deadlines, their consequences and how the rule is being interpreted, using, for that, doctrinal search and jurisprudence. In addition, the Labor Process and the Special Courts System are also affected by civil procedural law, and it is of great relevance to verify if the new counting rule has applicability in these fields. After this work was carried out, it was possible to perceive that there are considerable differences between the Courts in the scope of the counting of procedural deadlines, thus demonstrating that there is not yet a general acceptance of the innovation covered by the Procedural Charter in force.

Key words: Procedural deadlines. Working days. Civil Procedure Code. Counting.

\section{INTRODUÇÃO}

A Constituição Federal de 1988 preconiza que o devido processo legal é um Direito Fundamental inerente a todos os indivíduos e imprescindível para a aplicação do Poder Jurisdicional de forma justa, correta e isonômica. ${ }^{3}$ À vista disso, a jurisdição, assimilada como

\footnotetext{
${ }^{1}$ Acadêmico do Curso de Direito, da UNICNEC.

${ }^{2}$ Professora Dra. do Curso de Direito da UNICNEC.

${ }^{3}$ DIDIER Jr., Fredie. Curso de direito processual civil : introdução ao direito processual civil, parte geral e processo de conhecimento. 17 ed. Salvador: Ed. Jus Podivm, 2015. p. 63.
} 
um poder Estatal voltado à correta aplicação do direito positivado ao mundo dos fatos, está sempre em busca de garantir a pacificação social. ${ }^{4}$

Daí impõe-se uma atuação estatal baseada em regras, princípios e valores que permitam que os direitos lesionados ou ameaçados possam ser devidamente reparados ou protegidos. ${ }^{5}$ Dessa maneira, encontra-se na legislação infraconstitucional o regramento que definirá o modo em que será realizada a atividade jurisdicional civil, a saber, o Código de Processo Civil, lei que entrou em vigor no dia 18 de março de 2016.

Ao apreciar o conteúdo da legislação processual civil, nota-se que o legislador construiu a norma objetivando uma verdadeira constitucionalização do processo, ${ }^{6}$ pois o Novo Código foi totalmente insculpido e ordenado com base nos princípios constitucionais vigentes, inclusive trazendo-os expressamente em seu texto. Esse modelo constitucional do direito processual civil $^{7}$ fica facilmente perceptível em face de alguns dos princípios basilares do NCPC, como a celeridade processual, duração razoável do processo, contraditório, ampla defesa, boa-fé e cooperação.

Inovador e também polêmico, o Novo Código de Processo Civil Brasileiro é, talvez, o principal enfoque no campo das Ciências Jurídicas atuais, inexistindo qualquer surpresa com tal informação, pois a lei, ainda jovem, apresenta uma miríade de possibilidades e incertezas aos operadores e pensadores do Direito.

Não diferente é a situação concernente aos prazos processuais, tão importantes dentro do procedimento jurisdicional, pois ditam o ritmo processual e permitem que exista uma razoabilidade na duração do próprio processo, que possui, exatamente em razão dos prazos, uma essência temporal, ${ }^{8}$ progredindo, expandindo-se e sendo praticado no decorrer do tempo. ${ }^{9}$

\footnotetext{
${ }^{4}$ NEVES, Daniel Amorim Assumpção. Manual de direito processual civil. 8 ed. Salvador : Ed. Juspodivm, 2016. p. 1.

${ }^{5}$ BUENO, Cassio Scarpinella. Manual de direito processual civil : inteiramente estruturado à luz do novo CPC, de acordo com a Lei n. 13.256, de 4-2-2016. 2 ed. rev., atual. e ampl. São Paulo : Saraiva, 2016. p. 46.

${ }^{6}$ WAMBIER, Teresa Arruda Alvim Wambier. et. al. Primeiros comentários ao novo código de processo civil : artigo por artigo. Coordenação Teresa Arruda Alvim Wambier... [et al.]. 1 ed. São Paulo : Revista dos Tribunais, 2015. p. 50.

7 BUENO, Cassio Scarpinella. Manual de direito processual civil : inteiramente estruturado à luz do novo CPC, de acordo com a Lei n. 13.256, de 4-2-2016. 2 ed. rev., atual. e ampl. São Paulo : Saraiva, 2016. p. 41 a 43. ${ }^{8}$ MARINONI, Luz Guilherme; ARENHART, Sérgio Cruz; MITIDIERO, Daniel. Novo curso de processo civil: tutela dos direitos mediante procedimento comum. São Paulo : Revista dos Tribunais, 2015. 2 v. p. 118.

9 MOLINARO, Carlos Alberto; MILHORANZA, Mariângela Guerreiro. Tempo, Direito e Processo Brevíssimas Reflexões. Revista Páginas de Direito, Porto Alegre, ano 13, nº 1075, 03 de setembro de 2013.
} 
Nesse sentido, a nova lei processual apresentou alterações salutares com relação aos prazos processuais, modificando, principalmente, o modo em que será realizada a sua contagem em dias. Perante as atuais regras do Código de Processo Civil, as mudanças no procedimento jurisdicional frente à legislação revogada aparecem de forma nítida.

Fica evidente que há uma nova caminhada processual, o que abre mais um dos inúmeros leques de discussões no âmbito processual civil brasileiro e, naturalmente, predispõe à elaboração de produções acadêmicas, doutrinárias e jurisprudenciais. Além de verificar os novos rumos processuais civis, alcança relevância a pesquisa sobre as consequências causadas pela nova contagem dos prazos, mormente porque há diferentes visões a respeito da novidade, com ênfase à discussão sobre a regra ser um benefício ou malefício ao processo judicial.

Ainda, o processo civil não é o único a ser alcançado pela nova legislação, pois o Código de Processo Civil possui aplicabilidade em outros ramos e espécies processuais. Neste artigo, na intenção de delimitar a pesquisa, também se buscará investigar a aplicabilidade ou não do artigo 219 da Lei 13.105/2015 no âmbito do Processo Civil, Processo do Trabalho e no Sistema dos Juizados Especiais. Assim, objetiva-se verificar as mudanças aludidas pelo novel Código no que tange à contagem dos prazos processuais, bem como as suas repercussões práticas.

\section{PRAZOS PROCESSUAIS}

O processo desenvolve-se por meio de uma cadeia de acontecimentos que, de forma ordenada, levam-no a uma conclusão. Para isso, atos sucessivos vão acontecendo durante o andar da marcha processual, atos estes praticados pelas partes, juiz, serventuários de justiça e demais sujeitos envolvidos na relação processual. Esses atos recebem a denominação de "atos processuais". 10

Os atos processuais afiguram-se como uma das modalidades de ato jurídico, possuindo a finalidade de criar, modificar, conservar ou extinguir uma relação jurídica de natureza processual. ${ }^{11}$ Caracterizam-se por serem praticados de forma consciente, pois são

Disponível em: <http://www.tex.pro.br/home/artigos/173-artigos-jul-2013/4752-tempo-direito-e-processobrevissimas-reflexoes> Acesso em: 07 de abril de 2016.

${ }^{10}$ ALVIM, José Eduardo Carreira. Teoria Geral do Processo. 18 ed. Rio de Janeiro : Forense, 2015. p. 214.

${ }^{11}$ WAMBIER, Luiz Rodrigues. Curso avançado de processo civil: teoria geral do processo e processo de conhecimento. 15. ed. rev e ampl. São Paulo : Revista dos Tribunais, 2015. 1 v. p. 257. 
resultantes da vontade humana, ${ }^{12}$ devendo, necessariamente, ser hábeis a produzir efeitos dentro de um processo, seja no futuro, seja no presente. $^{13}$

Pontue-se que os atos processuais não devem ser confundidos com os chamados "fatos processuais", que não dependem da vontade humana, mas, mesmo assim, interferem e influenciam o processo. ${ }^{14}$ Conquanto detenham uma indubitável importância para o processo, a exemplo da morte de uma das partes, o que suspende o processo até que ocorra a habilitação dos herdeiros no feito, ${ }^{15}$ os fatos jurídicos não serão objeto de estudo neste artigo.

Realizados no curso processual, os atos processuais estão interligados, sucedendo uns aos outros de acordo com as regras processuais vigentes, sempre no objetivo de alcançar um determinado provimento jurisdicional. ${ }^{16}$ Como são de suma importância para a existência do processo, faz-se necessária a existência de uma cronologia, uma ordem temporal capaz de limitar o período da realização dos atos processuais. ${ }^{17}$

Por sua vez, os prazos são responsáveis por ditar o tempo dos atos processuais, o que consequentemente se exterioriza no tempo do processo. Nesse diapasão, extrai-se a motivação para a existência dos prazos processuais: a legislação tem o dever de impor condições que ensejem numa direção processual ao seu próprio fim, ou seja, a obtenção de uma decisão judicial terminativa. ${ }^{18}$

A hipótese de um processo praticado sem a existência de prazos não merece nem mesmo ser trazida à tona, pois nasceria um procedimento desordenado e, provavelmente,

\footnotetext{
${ }^{12}$ ALVIM, Angélica Arruda Alvim; ALVIM, Eduardo Arruda Alvim; PEREIRA FILHO, Benedito Cerezzo. Dos atos das partes. In: ALVIM, Angélica Arruda. et. al. Comentários ao código de processo civil. Coordenadores Angélica Arruda Alvim... [et. al.] 1 ed. São Paulo : Saraiva, 2016. p. 279-281.

${ }^{13}$ DIDIER Jr., Fredie. Curso de direito processual civil: introdução ao direito processual civil, parte geral e processo de conhecimento. 17 ed. Salvador : Ed. Jus Podivm, 2015. p. 374.

${ }^{14}$ BUENO, Cassio Scarpinella. Manual de direito processual civil : inteiramente estruturado à luz do novo CPC, de acordo com a Lei n. 13.256, de 4-2-2016. 2 ed. rev., atual. e ampl. São Paulo : Saraiva, 2016. p. 209.

${ }^{15} \mathrm{CPC} / 2015$ "Art. 313. Suspende-se o processo: I - pela morte ou pela perda da capacidade processual de qualquer das partes, de seu representante legal ou de seu procurador; [...]" (BRASIL. Lei ${ }^{\circ}$ 13.105/2015, de 16 de março de 2015. Diário Oficial da República Federativa. Brasília, DF, 16 de março de 2015. Disponível em: <http://www.planalto.gov.br/ccivil_03/_Ato2015-2018/2015/Lei/L13105.htm〉. Acesso em: 11 de março de 2016).

${ }^{16}$ WAMBIER, Luiz Rodrigues. Curso avançado de processo civil: teoria geral do processo e processo de conhecimento. 11. ed. rev e ampl. São Paulo : Revista dos Tribunais, 2010. 1 v. p. 250.

${ }^{17}$ MARINONI, Luz Guilherme; ARENHART, Sérgio Cruz; MITIDIERO, Daniel. Novo curso de processo civil: tutela dos direitos mediante procedimento comum. São Paulo: Revista dos Tribunais, 2015. 2 v. p. 118.

${ }^{18}$ ALVIM, Arruda. Manual de direito processual civil: parte geral. 9. ed. rev., atual e ampl. São Paulo : Revista dos Tribunais, 2005. v.1. p. 410.
} 
interminável. ${ }^{19}$ Não se pode vislumbrar um processo justo sem que exista uma limitação temporal para a realização dos atos que o compõem, bem como a fixação do momento em que esses atos devem ser exercidos. ${ }^{20}$

E é justamente em razão disso que os prazos processuais não podem ser estipulados de forma irrazoável. Cada ato processual deve ser dotado de um lapso temporal que outorgue à parte a plena capacidade de realizá-lo, não sendo correta a imposição de prazos que se revelem imprestáveis para o desenvolvimento do processo. Da mesma forma, nenhum prazo processual pode se prolongar demasiadamente pelo tempo, de modo que a agilidade na prestação jurisdicional seja prejudicada, assim como a própria solução do litígio. ${ }^{21}$

\subsection{Conceito de prazo}

Dentro de um enfoque processualista, o prazo deve ser entendido como o período ou interregno temporal em que deve ser praticado determinado ato processual. ${ }^{22}$ Aos prazos são atribuídas as funções precípuas de demarcar o tempo concedido aos integrantes do processo para que estes apresentem as suas posições jurídicas e defesa dos seus interesses, bem como abalizar o período de prática das diligências necessárias para o prosseguimento e resolução do feito. $^{23}$

O processamento ou prática de um ato processual ocorrerá dentro do espaço temporal que tenha sido estipulado pela lei (prazos legais, indisponíveis e geralmente imutáveis), ${ }^{24}$ pelo

\footnotetext{
${ }^{19}$ GRECO FILHO, Vicente. Direito Processual civil brasileiro: (atos processuais a recursos e processos nos tribunais). 20 ed. rev. e atual. São Paulo : Saraiva, 2009. 2 v. p. 22.

${ }^{20}$ MILHOMENS, Jônatas. Dos prazos e do tempo no Código de processo civil: incluídos comentários aos arts. 154 a 250. Rio de Janeiro : Forense, 1979. p. 7.

${ }^{21}$ TUPINAMBÁ, Carolina. O processo do trabalho e os novos prazos processuais do CPC/2015. In: BRANDÃO, Cláudio; MALLET, Estêvão. Coleção repercussões do novo CPC: Processo do Trabalho. Coordenadores Cláudio Brandão e Estêvão Mallet. $2^{\circ}$ ed. rev. e atual. Salvador : Juspodivm, 2016. 4 v. p. $247-$ 283.

${ }^{22}$ ACQUAVIVA, Marcus Cláudio. Dicionário Jurídico Brasileiro. 6 ed. São Paulo: Jurídica Brasileira, 1994. p. 980.

${ }_{23}$ MARINONI, Luz Guilherme; ARENHART, Sérgio Cruz; MITIDIERO, Daniel. Novo curso de processo civil: tutela dos direitos mediante procedimento comum. São Paulo: Revista dos Tribunais, 2015. 2 v. p. 118.

${ }^{24}$ WAMBIER, Luiz Rodrigues. Curso avançado de processo civil: teoria geral do processo e processo de conhecimento. 11. ed. rev e ampl. São Paulo : Revista dos Tribunais, 2010. 1 v. p. 251.
} 
juiz (em razão da omissão legal ou peculiaridades do caso) ${ }^{25}$ ou, ainda, por convenção das partes, os chamados "prazos convencionais". ${ }^{26}$

Os prazos começam a fluir no momento em que vêm à tona no processo judicial, ou seja, no momento em que iniciam sua existência, assim como devem ser contados a partir do instante em que forem computados para que seja possível chegar a sua própria extinção. ${ }^{27} \mathrm{Em}$ princípio, verificam-se dois conceitos: o de fluência e o de contagem. ${ }^{28}$ Além do termo "fluir", também pode ser utilizado o termo "correr" para denominar a passagem dos prazos no tempo.

Considerando a flexibilidade e possibilidade de dilação dos prazos processuais, encontram-se duas classificações: os prazos dilatórios e os prazos peremptórios. Os prazos dilatórios permitem uma flexibilidade, sendo modificáveis em razão da vontade do juiz ou das partes. ${ }^{29}$ De outra banda, os prazos peremptórios, ${ }^{30}$ que apresentam consequências processuais com o seu termo final, ${ }^{31}$ são inalteráveis pelas partes ou pelo Juízo, normalmente sendo prazos legais e direcionados à proteção do contraditório por estarem relacionados aos atos de respostas das partes e recursos. ${ }^{32}$

Outra classificação é referente a qual dos sujeitos processuais é destinado o prazo, ou seja, cuida dos prazos próprios e impróprios. Os prazos impróprios norteiam os atos processuais que são de responsabilidade do juiz e dos serventuários da justiça. Por outro lado, próprios são os prazos que estão ligados aos atos processuais que devem ser realizados pelas partes; desta forma, são passíveis de apresentar consequências processuais quando não realizados dentro do tempo estabelecido para a sua prática. ${ }^{33}$

\footnotetext{
${ }^{25}$ Ibidem, p. 252.

${ }^{26}$ NEVES, Iedo Batista. Vocabulário prático de tecnologia jurídica e de brocardos latinos. 5 ed. rev. e ampl. Rio de Janeiro : Fase, 1992. Não paginado.

${ }^{27}$ OLIVEIRA, Carlos Alberto Alvaro de; MITIDIERO, Daniel. Curso de processo civil: teoria geral do processo civil e parte geral do direito processual civil. São Paulo, Atlas, 2010. 1 v. p. 293.

${ }^{28}$ MARINONI, op. cit., p. 119.

${ }^{29}$ THEODORO JÚNIOR, Humberto. Curso de Direito Processual Civil - Teoria geral do direito processual civil e processo de conhecimento. Rio de Janeiro : Forense, 2011. p. 256.

${ }^{30}$ A origem da palavra "peremptório" vem do vocábulo "perempção", que, por sua vez, é oriunda do termo latino "peremptione", que significa destruição, extinção. Tais termos só são aplicados no âmbito processual, não existindo a perempção de direito material. (ACQUAVIVA, Marcus Cláudio. Dicionário Jurídico Brasileiro. 6 ed. São Paulo : Jurídica Brasileira, 1994. p. 932).

${ }^{31}$ THEODORO JÚNIOR, op. cit., p. 257.

${ }^{32}$ GRECO FILHO, Vicente. Direito Processual civil brasileiro: (atos processuais a recursos e processos nos tribunais). 20 ed. rev. e atual. São Paulo : Saraiva, 2009. 2 v. p. 24.

${ }^{33}$ WAMBIER, Luiz Rodrigues. Curso avançado de processo civil: teoria geral do processo e processo de conhecimento. 11. ed. rev e ampl. São Paulo : Revista dos Tribunais, 2010. 1 v. p. 252-253.
} 
A principal sequela da perda de um prazo próprio é a extinção do direito da parte praticar aquele ato específico, ${ }^{34}$ o que abre espaço para o aparecimento do fenômeno da preclusão temporal, existente apenas na esfera processual e que está ligado diretamente à indispensabilidade de o processo alcançar o seu próprio fim. ${ }^{35}$ No que tange aos prazos impróprios, mesmo quando ultrapassado o período estipulado pela lei para a sua prática, haverá eficácia no ato processual realizado, inexistindo, na prática, qualquer espécie de punição para aquele que perdeu o prazo. ${ }^{36}$

Além disso, existem os prazos comuns e individuais. Comum é o prazo que se aplica às partes sem a existência de distinções, fluindo da mesma maneira para autor e réu. ${ }^{37}$ Individual é o prazo que é dado para apenas uma das partes, contrário, portanto, ao prazo denominado comum.

Ainda, conforme leciona Carreira Alvim, existem os prazos considerados especiais, que, em razão de uma maior dilatação, beneficiam apenas uma das partes, normalmente porque o beneficiado recebe tratamento legal diferenciado por causa de sua natureza, como acontece com o Ministério Público, Fazenda Pública e Defensoria Pública, por exemplo. ${ }^{38}$

É elementar entender que os prazos especiais não servem como uma vantagem injusta conferida a determinadas figuras dentro do processo judicial, pois dada a alta carga de trabalho, interesses amparados, dificuldades burocráticas e, não raramente, ausência de infraestrutura que permita uma atuação mais célere e eficiente, evidenciada fica a inevitabilidade de existir um período mais amplo para a prática dos atos processuais pelos Órgãos Públicos. ${ }^{39}$

A expressão prazo "processual" e o vocábulo "termo" possuem significados distintos, visto que o segundo é, na verdade, um elemento essencial para a existência do primeiro, porque um prazo processual só é verificável quando estiver presente um termo inicial (dies a quo) e um termo final (dies ad quem), ou seja, uma fração de tempo predeterminada. ${ }^{40}$

\footnotetext{
${ }^{34}$ GRECO FILHO, op. cit., p. 24.

${ }^{35}$ WAMBIER, op. cit., p. 311.

${ }^{36}$ NEVES, Daniel Amorim Assumpção. Manual de direito processual civil. 8 ed. Salvador : Ed. Juspodivm, 2016. p. 357.

${ }^{37}$ ALVIM, Arruda. Manual de direito processual civil: parte geral. 9. ed. rev., atual e ampl. São Paulo : Revista dos Tribunais, 2005.1 v. p. 422

${ }^{38}$ ALVIM, José Eduardo Carreira. Teoria Geral do Processo. 18 ed. Rio de Janeiro: Forense, 2015. p. 217.

${ }^{39}$ GRECO FILHO, Vicente. Direito Processual civil brasileiro: (atos processuais a recursos e processos nos tribunais) - 20 ed. rev. e atual. - São Paulo : Saraiva 2009. 2 v. p. 27.

${ }^{40}$ ALVIM, José Eduardo Carreira, op. cit., p. 215.
} 
Há dois brocardos jurídicos que sintetizam essa regra: dies a quo nom computatur in termino (o dia do começo não será computado no prazo) e dies ad quem computatur in termino (o dia do vencimento será incluído no cômputo do prazo). ${ }^{41} \mathrm{O}$ dies a quo concebe à parte a faculdade para promover determinado ato capaz de influenciar no processo, enquanto o dies ad quem encerra essa possibilidade, tendo ou não o ato sido praticado. ${ }^{42}$

\subsection{O tempo processual}

O estudo dos prazos processuais acarreta, por consequência da sua própria qualidade, uma análise do tempo em que são praticados os atos processuais. Atualmente, o tempo da realização dos atos processuais está fixado nos artigos 212 a 216 do Novo Código de Processo Civil.

Os atos processuais devem ser praticados dentro do prazo fixado na lei ou, no caso de omissão ou possibilidade de flexibilização, de acordo com o que for determinado pelo Órgão Judicante. ${ }^{43}$ Para Humberto Theodoro Júnior, a prática de um ato processual deve ser vista por duas perspectivas ou ângulos: 1) pelo prazo previamente estabelecido para aquele determinado ato; 2) pelo momento que se mostrar adequado ou útil para uma determinada atividade processual. $^{44}$

Para que os prazos processuais possam ser constatados, o tempo deve ser identificado como o seu fato gerador. O tempo, aliás, é inafastável das dimensões fundamentais da vida humana ${ }^{45}$ permeando toda a sua existência. Não obstante, seus efeitos atuam diretamente na eficácia dos atos processuais e do processo em si. $^{46}$

Semelhante ao tempo, o processo deve sempre ser impulsionado para frente, seja por um caminho preordenado pela lei, seja por meio de uma determinação judicial ou

41 TUPINAMBÁ, Carolina. O processo do trabalho e os novos prazos processuais do CPC/2015. In: BRANDÃO, Cláudio; MALLET, Estêvão. Coleção repercussões do novo CPC: Processo do Trabalho. Coordenadores Cláudio Brandão e Estêvão Mallet. $2^{\circ}$ ed. rev. e atual. Salvador : Juspodivm, 2016. 4 v. p. $247-$ 283.

${ }^{42}$ PEIXOTO, Ulisses Vieira Moreira. Os prazos no novo código de processo civil. $1^{\text {a }}$ ed. Campo Grande : Contemplar, 2016. p. 23.

${ }^{43}$ MARINONI, Luz Guilherme; ARENHART, Sérgio Cruz; MITIDIERO, Daniel. Novo curso de processo civil: tutela dos direitos mediante procedimento comum. São Paulo: Revista dos Tribunais, 2015. 2 v. p. 118.

44 THEODORO JÚNIOR, Humberto. Curso de Direito Processual Civil - Teoria geral do direito processual civil e processo de conhecimento. Rio de Janeiro: Forense, 2011. p. 252.

45 ALVIM, Arruda. Manual de direito processual civil: parte geral. 9. ed. rev., atual e ampl. São Paulo : Revista dos Tribunais, 2005. 1 v. p. 410.

${ }^{46}$ ALVIM, José Eduardo Carreira. Teoria Geral do Processo. 18 ed. Rio de Janeiro: Forense, 2015. p. 216. 
convencionada pelas partes. O liame entre o tempo e o processo é inquebrável, pois o primeiro é o responsável por fazer o segundo avançar e atingir o seu fim. ${ }^{47}$ Diz-se, então, que o processo é como um movimento no tempo, formado por atos sucessivos que devem levá-lo à frente. ${ }^{48}$

A partir dessa premissa, é possível constatar o chamado dinamismo processual, uma característica não encontrada no direito material, visto que este é, em regra, composto de relações instantâneas. Esse dinamismo decorre diretamente do fato de a relação jurídica processual ser continuada, construindo-se durante o tempo até o seu final durante determinado período. ${ }^{49}$ Por isso, existe a concepção de que o processo deve sempre "seguir adiante" ou "ir em frente", sendo conduzido até a resolução da questão trazida ao juízo por meio da prolação de uma sentença de mérito. ${ }^{50}$

\section{A CONTAGEM DOS PRAZOS PROCESSUAIS DE ACORDO COM O CÓDIGO DE PROCESSO CIVIL BRASILEIRO DE 1973}

Este capítulo visa à realização de uma breve apreciação sobre o modo de contagem dos prazos processuais conforme o Código de Processo Civil de 1973, revogado pela Lei $13.105 / 15$.

\subsection{A forma de contagem dos prazos processuais na sistemática do Código de Processo} Civil de 1973

A regra geral da contagem dos prazos processuais no Código de 1973 era simples: excluía-se o dia do começo e incluía-se o dia em que ocorresse o vencimento do prazo. ${ }^{51}$ Isso

\footnotetext{
47 MOLINARO, Carlos Alberto; MILHORANZA, Mariângela Guerreiro. Tempo, Direito e Processo Brevíssimas Reflexões. Revista Páginas de Direito, Porto Alegre, ano 13, nº 1075, 03 de setembro de 2013. Disponível em: <http://www.tex.pro.br/home/artigos/173-artigos-jul-2013/4752-tempo-direito-e-processobrevissimas-reflexoes> Acesso em: 07 de abril de 2016.

${ }^{48}$ MILHOMENS, Jônatas. Dos prazos e do tempo no Código de processo civil : incluídos comentários aos arts. 154 a 250. Rio de Janeiro : Forense, 1979. p. 8.

${ }^{49}$ NEVES, Daniel Amorim Assumpção. Manual de direito processual civil. 8 ed. Salvador : Ed. Juspodivm, 2016. p. 103

${ }^{50}$ WAMBIER, Luiz Rodrigues. Curso avançado de processo civil: teoria geral do processo e processo de conhecimento. 15. ed. rev e ampl. São Paulo : Revista dos Tribunais, 2015. 1 v. p. 297.

${ }^{51}$ CPC/1973 “Art. 184. Salvo disposição em contrário, computar-se-ão os prazos, excluindo o dia do começo e incluindo o do vencimento." (BRASIL. Lei no 5.869/73, de 11 de janeiro de 1973. Código de Processo Civil.
} 
decorre da necessidade de que a parte obtenha a plena possibilidade de usufruir de todo o período que lhe é dado para praticar determinado ato dentro do processo, pois, caso a contagem fosse iniciada no mesmo dia da citação, intimação, ou de qualquer outro fato que indicasse a ciência da manifestação judicial, existiria uma clara redução do prazo estipulado, prejudicando, assim, a prática do próprio ato processual. ${ }^{52}$

Além disso, para que o prazo pudesse iniciar a sua fluência ou ter reconhecido o seu término, havia a necessidade de considerar apenas os dias úteis, mesmo que o termo inicial ou o termo final fossem fixados em dias em que não havia expediente forense. ${ }^{53}$ Como exemplo, uma intimação que tivesse se dado em uma sexta-feira ocasionava com que o prazo só iniciasse a sua fluência na segunda-feira da outra semana ou, ainda, no próximo dia útil. ${ }^{54}$

Em relação ao termo final da contagem, três hipóteses permitiam o alongamento do espaço temporal de um prazo até o primeiro dia útil subsequente, todas elas relativas à normalidade e atividade do expediente forense: ${ }^{55}$ 1) prazo em que o vencimento ocorria em feriado; 2) em dias em que não havia expediente forense; 3) na eventualidade, dias em que o expediente forense era encerrado antes do horário habitual. ${ }^{56}$

Quanto à forma de contagem, a previsão consistia na continuidade dos prazos, independentemente da existência de feriado, ausência de expediente forense ou outras situações que encurtassem a atividade judiciária, desde que não verificado algum motivo de suspensão do curso da contagem. ${ }^{57}$

Diário Oficial da República Federativa. Brasília, DF, 11 de janeiro de 1973. Disponível em: <http://www.planalto.gov.br/ccivil_03/leis/L5869.htm>. Acesso em: 11 de março de 2016).

52 THEODORO JÚNIOR, Humberto. Curso de Direito Processual Civil - Teoria geral do direito processual civil e processo de conhecimento. Rio de Janeiro: Forense, 2011. p. 258.

53 ALVIM, Arruda. Manual de direito processual civil: parte geral. 9. ed. rev., atual e ampl. São Paulo : Revista dos Tribunais, 2005. 1 v. p. 424.

${ }^{54}$ BRASIL. Superior Tribunal Federal. Súmula 310: Quando a intimação tiver lugar na sexta-feira, ou a publicação com efeito de intimação for feita nesse dia, o prazo judicial terá início na segunda-feira imediata, salvo se não houver expediente, caso em que começará no primeiro dia útil que se seguir. Disponível em < http://www.stf.jus.br/portal/cms/verTexto.asp?servico=jurisprudenciaSumula\&pagina=sumula_301_400> Acesso em: 14 de abril de 2016.

55 THEODORO JÚNIOR, Humberto. Curso de Direito Processual Civil - Teoria geral do direito processual civil e processo de conhecimento. Rio de Janeiro: Forense, 2011. p. 263.

${ }^{56}$ CPC/1973 “Art. 184. Salvo disposição em contrário, computar-se-ão os prazos, excluindo o dia do começo e incluindo o do vencimento. $\S 1$ o Considera-se prorrogado o prazo até o primeiro dia útil se o vencimento cair em feriado ou em dia em que: I - for determinado o fechamento do fórum; II - o expediente forense for encerrado antes da hora normal.“ (BRASIL. Lei n n $^{\circ} .869 / 73$, de 11 de janeiro de 1973. Código de Processo Civil. Diário Oficial da República Federativa. Brasília, DF, 11 de janeiro de 1973. Disponível em: <http://www.planalto.gov.br/ccivil_03/leis/L5869.htm>. Acesso em: 11 de março de 2016).

57 CPC/1973 "Art. 180. Suspende-se também o curso do prazo por obstáculo criado pela parte ou ocorrendo qualquer das hipóteses do art. 265, I e III; casos em que o prazo será restituído por tempo igual ao que faltava 


\subsection{Análise jurisprudencial}

Com o fim de resgatar e exemplificar o modo em que se dava a contagem dos prazos processuais na vigência do Código de Processo Civil de 1973, foram selecionadas três ementas oriundas de julgados do Tribunal de Justiça do Rio Grande do Sul.

TEMPESTIVIDADE RECURSAL. OCORRÊNCIA. REPRESENTAÇÃO PROCESSUAL. DEFEITO. REVELIA. RESPONSABILIDADE CIVIL. TRANSPORTADOR. ASSALTO. FORTUITO EXTERNO. O prazo para a contagem da tempestividade do recurso se inicia no dia imediatamente posterior à publicacão da decisão recorrida, desde que se trate de dia útil, não sendo essa a hipótese dos autos, mormente porque tal data se tratava de feriado nacional. Verificada a irregularidade de representação processual e intimada a requerida para sanar o defeito, nada fazendo, impõe-se a decretação da revelia. Seus efeitos, porém, geram presunção relativa quanto à veracidade dos fatos narrados na exordial. No caso, não restou evidenciada qualquer conduta do preposto da requerida que tenha contribuído para o assalto sofrido. Fortuito externo que afasta o dever de indenizar, pois se trata de causa excludente da responsabilidade civil (CDC, art. 14, $\S 3^{\circ}$, II). REJEITADA A PRELIMINAR DA INTEMPESTIVIDADE. ACOLHIDA A DE IRREGULARIDADE DA REPRESENTAÇÃO PROCESSUAL. REVELIA DECRETADA. APELO PARCIALMENTE PROVIDO. NO MÉRITO, SENTENÇA MANTIDA. ${ }^{58}$ (grifou-se)

O trecho selecionado do acórdão acima colacionado é decorrente da irresignação da parte apelada com a interposição do recurso, que, segundo seu entendimento, seria intempestivo, motivo pelo qual o recurso não deveria ser conhecido. O julgado, contudo, reconheceu a tempestividade do recurso, pois a data de publicação da sentença era procedida por feriado, o que fez o início da contagem ocorresse apenas no dia útil seguinte.

PROCESSUAL CIVIL. MANDADO JUNTADO DURANTE PERÍODO DE SUSPENSÃO DOS PRAZOS. INÍCIO DA CONTAGEM. Juntado o mandado de citacão em período em que os prazos processuais se encontravam suspensos, 0 início da contagem dá-se no primeiro dia útil após o término da causa suspensiva, o qual deve ser incluído no cômputo. Inteligência dos arts. 179 e 184, caput, ambos do CPC. Agravo provido em decisão monocrática. ${ }^{59}$ (grifou-se)

para a sua complementação.” (BRASIL. Lei no 5.869/73, de 11 de janeiro de 1973. Código de Processo Civil. Diário Oficial da República Federativa. Brasília, DF, 11 de janeiro de 1973. Disponível em: <http://www.planalto.gov.br/ccivil_03/leis/L5869.htm>. Acesso em: 11 de março de 2016).

${ }^{58}$ RIO GRANDE DO SUL. Tribunal de Justiça. Décima Câmara Cível. Apelação Cível n. 70017285024 Comarca de Canoas. Relator: Luiz Ary Vessini de Lima, 22 mar. 2007. Diário da Justiça, Porto Alegre, 10 de abril de 2007.

${ }^{59}$ RIO GRANDE DO SUL. Tribunal de Justiça. Décima Câmara Cível. Agravo de Instrumento n. 70008695660 - Comarca de Santa Cruz do Sul. Relator: Jorge Alberto Schreiner Pestana, 06 mai. 2004. Diário da Justiça, Porto Alegre, 11 mai. 2004. 
Aplicando o disposto no artigo 184 do Código de Processo Civil de 1973, a Turma Julgadora decidiu que a contagem do prazo processual só poderia ser iniciada no $1^{\circ}$ dia útil após o período de suspensão dos prazos, o que influiu no reconhecimento da tempestividade da apresentação da contestação.

\begin{abstract}
AGRAVO DE INSTRUMENTO. DIREITO PRIVADO NÃO ESPECIFICADO. PROCESSUAL CIVIL. INTEMPESTIVIDADE DO RECURSO DE APELAÇÃO. DECISÃO REFORMADA. Suspensão dos prazos processuais no período de 20/12/2011 a 13/01/2012. Inteligência do artigo $1^{\circ}$ do Ato 09/2011 deste Tribunal. Suspenso o prazo durante as férias forenses, reinicia-se a contagem no primeiro dia útil subseqüente ao término. Aplicacão conjunta dos artigos 179 e 508 do CPC com os parágrafos $3^{\circ}$ e $4^{\circ}$, do artigo $4^{\circ}$, da Lei 11.419/2006. Em decisão monocrática, dou provimento ao agravo de instrumento. ${ }^{60}$ (grifou-se)
\end{abstract}

Entendeu a turma julgadora que a suspensão dos prazos em decorrência das férias forenses, além de acarretar na óbvia estagnação do cômputo dos prazos no dia útil anterior ao período de descanso, permite o retorno da contagem unicamente após o término desse intervalo temporal, no $1^{\circ}$ dia útil a ele subsequente.

Denota-se que o posicionamento adotado pela Corte Gaúcha era praticamente uníssono, reconhecendo apenas os dias úteis como os marcos de início e de término da contagem dos prazos processuais. Não obstante, nenhum dos julgados deixa de aplicar a contagem dos prazos de acordo com o Código revogado, ou seja, de forma contínua, fórmula que foi superada com o advento do Novo Código de Processo Civil.

\title{
4 A CONTAgem dos PRAzos PROCESSUAis No Código de PROCESSO CIVIL BRASILEIRO DE 2015
}

Os prazos processuais civis, hodiernamente, têm suas disposições gerais reguladas no Livro IV, Título I, Capítulo III, do Código de Processo Civil vigente, permanecendo, assim, na seção dedicada aos atos processuais. Além dos dispositivos gerais, a Nova Lei Processual apresenta um vasto regramento quanto a atos processuais específicos, sejam eles referentes ao procedimento comum, sejam eles os procedimentos especiais entabulados nos 1.072 (mil e setenta e dois) artigos constantes no texto legal.

\footnotetext{
${ }^{60}$ RIO GRANDE DO SUL. Vigésima Câmara Cível. Agravo de Instrumento no 70048250807 - Comarca de Porto Alegre. Relator: Glênio José Wasserstein Hekman, 09 abr. 2012. Diário da Justiça, Porto Alegre, 13 abr. 2012.
} 
A principal alteração atinente aos prazos processuais é a que está inclusa no artigo 219 do CPC. ${ }^{61}$ Por meio desse dispositivo, há a regra de que o prazo contado em dias, seja ele estabelecido pela lei, seja pelo juiz, apenas será computado durante os dias úteis. A disposição exclui a possibilidade de contagem de prazos processuais em dias não úteis, quais sejam: sábados, domingos, feriados e datas em que não ocorra expediente forense.

É valioso pontuar que a nova regra de contagem se aplica unicamente aos prazos processuais e não aos prazos de direito material. ${ }^{62}$ Sendo assim, os prazos para a prescrição e a decadência, por exemplo, continuarão a ser contados de forma contínua, pois não se trata de institutos processuais. ${ }^{63} \mathrm{Na}$ mesma situação estão incluídos os prazos para o cumprimento de obrigações determinadas por decisão judicial ${ }^{64}$ ou contraídas por intermédio de negócios jurídicos. $^{65}$

Mostra-se necessária a conjugação do artigo 219 às disposições contidas no capítulo que rege o tempo e o lugar dos atos processuais no processo civil brasileiro (arts. 212 a 216 do (PC), haja vista a importância de conhecer quais são os dias considerados úteis pela legislação processual. Assim, segundo o regramento atual, são considerados dias úteis os dias da semana de segunda a sexta-feira, desde que as datas não recaíam em feriados ou dias em que não se verificar a atividade forense. ${ }^{66}$

Esclarecedor, o artigo 216 do CPC facilita a verificação dos dias que não serão considerados na contagem dos prazos processuais, pois declara que o dia em que não ocorrer o expediente forense será considerado automaticamente como feriado, cognição que engloba, também, os sábados e domingos. ${ }^{67}$ A novidade, aqui, está no fato de que os sábados não são

${ }^{61}$ CPC/2015 "Art. 219. Na contagem de prazo em dias, estabelecido por lei ou pelo juiz, computar-se-ão somente os dias úteis.” (BRASIL. Lei n 13.105/2015, de 16 de março de 2015. Diário Oficial da República Federativa. Brasília, DF, 16 de março de 2015. Disponível em: <http://www.planalto.gov.br/ccivil_03/_Ato2015-2018/2015/Lei/L13105.htm>. Acesso em: 11 de março de 2016).

${ }^{62}$ WAMBIER, Teresa Arruda Alvim Wambier. et. al. Primeiros comentários ao novo código de processo civil: artigo por artigo. Coordenação Teresa Arruda Alvim Wambier... [et al.]. 1 ed. São Paulo : Revista dos Tribunais, 2015. p. 388.

${ }^{63}$ NEVES, Daniel Amorim Assumpção. Manual de direito processual civil. 8 ed. Salvador : Ed. Juspodivm, 2016.p. 360.

${ }^{64}$ Ibidem. p. 359.

${ }^{65}$ BUENO, Cassio Scarpinella. Manual de direito processual civil: inteiramente estruturado à luz do novo CPC, de acordo com a Lei n. 13.256, de 4-2-2016. 2 ed. rev., atual. e ampl. São Paulo : Saraiva, 2016. p. 223.

${ }_{66}$ MACEDO, Elaine Harzheim. Comentários aos artigos 218 ao 232. In: ORDEM DOS ADVOGADOS DO BRASIL (org). Novo código de processo civil anotado. Porto Alegre : OAB/RS, 2015. p. 192-195.

${ }^{67} \mathrm{CPC} / 2015$ "Art. 216. Além dos declarados em lei, são feriados, para efeito forense, os sábados, os domingos e os dias em que não haja expediente forense." (BRASIL. Lei n ${ }^{\circ} 13.105 / 2015$, de 16 de março de 2015. Diário 
mais percebidos como dias úteis para efeitos forenses, ${ }^{68}$ superando a regra já há muito defasada do artigo 175 do CPC/73, que levava à assimilação de que os sábados eram contados como dias em que havia expediente forense. ${ }^{69}$

$\mathrm{O}$ artigo 220 do $\mathrm{CPC} / 2015^{70}$ aponta outros dias que não serão considerados como úteis na esfera forense, visto que prevê a suspensão do curso dos prazos processuais entre as datas de 20 de dezembro e 20 de janeiro, período no qual não serão aprazadas nem mesmo audiências ou sessões de julgamento. Contudo, a atividade jurisdicional seguirá suas atividades durante o período estipulado pelo artigo em comento, em plena consonância com a Constituição Federal, ${ }^{71}$ ficando garantida a autonomia dos Órgãos elaborarem os quadros de férias dos seus integrantes. ${ }^{72}$

A regra supracitada garante que os advogados gozem de férias sem precisar aguardar pelas determinações dos Tribunais, que todos os anos publicam provimentos fixando os dias em que não correrão os prazos. ${ }^{73}$ A imposição do Código uniformiza o período de recesso forense, impossibilitando a discordância entre os Tribunais quanto à matéria.

Oficial da República Federativa. Brasília, DF, 16 de março de 2015 . Disponível em: <http://www.planalto.gov.br/ccivil_03/_Ato2015-2018/2015/Lei/L13105.htm>. Acesso em: 11 de março de 2016).

${ }^{68}$ WAMBIER, Teresa Arruda Alvim Wambier. et. al. Primeiros comentários ao novo código de processo civil: artigo por artigo. Coordenação Teresa Arruda Alvim Wambier... [et al.]. 1 ed. São Paulo : Revista dos Tribunais, 2015. p 384.

${ }^{69}$ CPC/1973 “Art. 175. São feriados, para efeito forense, os domingos e os dias declarados por lei." (BRASIL. Lei n $n^{\circ}$ 5.869/73, de 11 de janeiro de 1973. Código de Processo Civil. Diário Oficial da República Federativa. Brasília, DF, 11 de janeiro de 1973. Disponível em: 〈http://www.planalto.gov.br/ccivil_03/leis/L5869.htm>. Acesso em: 11 de março de 2016).

${ }^{70} \mathrm{CPC} / 2015$ "Art. 220. Suspende-se o curso do prazo processual nos dias compreendidos entre 20 de dezembro e 20 de janeiro, inclusive. $§ 1$ o Ressalvadas as férias individuais e os feriados instituídos por lei, os juízes, os membros do Ministério Público, da Defensoria Pública e da Advocacia Pública e os auxiliares da Justiça exercerão suas atribuições durante o período previsto no caput.§ 2o Durante a suspensão do prazo, não se realizarão audiências nem sessões de julgamento." (BRASIL. Lei no 13.105/2015, de 16 de março de 2015. Diário Oficial da República Federativa. Brasília, DF, 16 de março de 2015. Disponível em: <http://www.planalto.gov.br/ccivil_03/_Ato2015-2018/2015/Lei/L13105.htm>. Acesso em: 11 de março de 2016).

${ }^{71}$ CF/88 “Art. 93 . Lei complementar, de iniciativa do Supremo Tribunal Federal, disporá sobre o Estatuto da Magistratura, observados os seguintes princípios:[...] XII. a atividade jurisdicional será ininterrupta, sendo vedado férias coletivas nos juízos e tribunais de segundo grau, funcionando, nos dias em que não houver expediente forense normal, juízes em plantão permanente;[...] (BRASIL. Constituição da República Federativa do Brasil. Diário Oficial da República Federativa. Brasília, DF, 05 de outubro de 1988. Disponível em: <http://www.planalto.gov.br/ccivil_03/leis/constituicao/constituicaocompilado>. Acesso em: 25 de setembro de 2016).

${ }^{72}$ SOUZA, Marcel Brasil. Cômputo dos prazos. In: CRUZ E TUCCI, José Rogério. Coleção repercussões do Novo CPC: Advocacia. Coordenador José Rogério Cruz e Tucci. Salvador : Juspodivm, 2015. 2 v. p. 34-40.

73 ZARIF, Claudio Cintra. Dos prazos. In: ALVIM, Angélica Arruda. et. al. Comentários ao código de processo civil. Coordenadores Angélica Arruda Alvim... [et. al.] 1 ed. São Paulo : Saraiva, 2016. p. 292-300. 
É conveniente referir que a demarcação do termo inicial e final da contagem dos prazos processuais definidos em dias é feita excluindo-se a data do começo, normalmente a data da publicação do ato ou o momento em que a parte toma ciência daquilo que deve ser praticado, e incluindo-se a data do término, contando, agora, apenas os dias úteis desse interregno temporal. ${ }^{74}$ Veja-se que o novel Código seguiu a regra constante no Código de Processo Civil de 1973, tradicional no ordenamento jurídico brasileiro. ${ }^{75}$

Cumpre mencionar o fato de que a forma de contagem estabelecida pelo artigo 219 do Código de Processo Civil vigente é estrita aos prazos processuais de origem legal ou judicial, sendo silente quanto a sua aplicação aos prazos estabelecidos pelas partes. Nesse caso, os prazos, denominados convencionais, são determinados por meio de negócio jurídico processual, ${ }^{76}$ havendo posicionamento no sentido de que deverá ser adotada a regra de contagem conforme dispõe o Novo CPC..$^{77}$

O disposto no artigo 219 do CPC pode levar ao entendimento de que a contagem dos prazos será feita sempre em dias, o que é costumeiro no processo civil. Entretanto, nada impede que a contagem dos prazos processuais, dada as peculiaridades de cada caso, seja

\footnotetext{
${ }^{74}$ MACEDO, Elaine Harzheim. Comentários aos artigos 218 ao 232. In ORDEM DOS ADVOGADOS DO BRASIL (org). Novo código de processo civil anotado. Porto Alegre : OAB/RS, 2015. p. 192-195.

${ }^{75} \mathrm{CPC} / 2015$ "Art. 224. Salvo disposição em contrário, os prazos serão contados excluindo o dia do começo e incluindo o dia do vencimento. $\S 1$ o Os dias do começo e do vencimento do prazo serão protraídos para o primeiro dia útil seguinte, se coincidirem com dia em que o expediente forense for encerrado antes ou iniciado depois da hora normal ou houver indisponibilidade da comunicação eletrônica. § 2o Considera-se como data de publicação o primeiro dia útil seguinte ao da disponibilização da informação no Diário da Justiça eletrônico. § 30 A contagem do prazo terá início no primeiro dia útil que seguir ao da publicação." (BRASIL. Lei n 13.105/2015, de 16 de março de 2015. Diário Oficial da República Federativa. Brasília, DF, 16 de março de 2015. Disponível em: <http://www.planalto.gov.br/ccivil_03/_Ato2015-2018/2015/Lei/L13105.htm>. Acesso em: 11 de março de 2016).

${ }^{76} \mathrm{CPC} / 2015$ "Art. 190. Versando o processo sobre direitos que admitam autocomposição, é lícito às partes plenamente capazes estipular mudanças no procedimento para ajustá-lo às especificidades da causa e convencionar sobre os seus ônus, poderes, faculdades e deveres processuais, antes ou durante o processo. Parágrafo único. De ofício ou a requerimento, o juiz controlará a validade das convenções previstas neste artigo, recusando-lhes aplicação somente nos casos de nulidade ou de inserção abusiva em contrato de adesão ou em que alguma parte se encontre em manifesta situação de vulnerabilidade.

Art. 191. De comum acordo, o juiz e as partes podem fixar calendário para a prática dos atos processuais, quando for o caso. § 1o O calendário vincula as partes e o juiz, e os prazos nele previstos somente serão modificados em casos excepcionais, devidamente justificados. § 2o Dispensa-se a intimação das partes para a prática de ato processual ou a realização de audiência cujas datas tiverem sido designadas no calendário." (BRASIL. Lei n 13.105/2015, de 16 de março de 2015. Diário Oficial da República Federativa. Brasília, DF, 16 de março de 2015. Disponível em: <http://www.planalto.gov.br/ccivil_03/_Ato2015-2018/2015/Lei/L13105.htm>. Acesso em: 11 de março de 2016).

${ }^{77}$ WAMBIER, Teresa Arruda Alvim Wambier. et. al. Primeiros comentários ao novo código de processo civil: artigo por artigo. Coordenação Teresa Arruda Alvim Wambier... [et al.]. 1 ed. São Paulo : Revista dos Tribunais, 2015. p. 388.
} 
realizada em minutos, horas, dias, meses ou anos, sendo que tudo dependerá do tipo do ato processual e do momento em que ele deva ser praticado. ${ }^{78}$

\section{AS IMPLICAÇÕES PRÁTICO JURÍDICAS DO ARTIGO 219 DO NOVO CÓDIGO DE PROCESSO CIVIL}

Em virtude de a Lei 13.105/2015 ter entrado em vigor no exato ano em que se apresenta este trabalho, ainda não houve a consolidação de entendimentos acerca da aplicação prática da nova legislação. Não há, portanto, uma posição majoritária nos Tribunais quanto ao modo em que será efetuado o cômputo dos prazos processuais em outros ramos do direito.

Incorporando a doutrina e discussões suscitadas sobre o tema, serão avocadas, neste capítulo, as previsões e suposições relativas à contagem dos prazos processuais nos ramos do Processo Civil, Processo do Trabalho e Sistema dos Juizados Especiais.

\subsection{Processo Civil}

A contagem dos prazos apenas levando em conta os dias úteis apresenta-se não só como uma novidade, mas como uma grandiosa benesse ao processo civil, pois além de permitir um maior período para a realização dos atos processuais, evita que a atividade, principalmente do advogado, tenha que ser realizada em curtos espaços de tempo ou em momentos destinados ao descanso e lazer. ${ }^{79}$

Em uma situação hipotética, aplicando o artigo 219 do Código de Processo Civil e tomando como parâmetro o prazo para a apresentação de embargos de declaração (cinco dias), com início da contagem em uma quinta-feira, o dies ad quo para a realização do ato seria na quarta-feira da semana posterior, porque o período do final de semana não pode ser levando em consideração no cômputo, pois não é composto por dias úteis. Se o prazo fosse contado na forma do Código revogado, expiraria na segunda-feira da semana posterior, dois dias antes do termo final da contagem consoante a legislação vigente.

\footnotetext{
${ }^{78}$ MARINONI, Luz Guilherme; ARENHART, Sérgio Cruz; MITIDIERO, Daniel. Novo curso de processo civil: tutela dos direitos mediante procedimento comum. São Paulo: Revista dos Tribunais, 2015. 2 v. p. 120.

${ }^{79}$ WAMBIER, Teresa Arruda Alvim Wambier. et. al. Primeiros comentários ao novo código de processo civil: artigo por artigo. Coordenação Teresa Arruda Alvim Wambier... [et al.]. 1 ed. São Paulo : Revista dos Tribunais, 2015. p. 387.
} 
Inegavelmente, a nova forma de contagem dos prazos aumenta o espaço temporal para a prática de um ato processual, o que é natural, pois não mais se consideram os dias em que não há expediente forense. Por esta ótica, é previsível que será instaurada discussão quanto ao fato de que a nova legislação criou óbice à celeridade processual, avolumando a duração do processo e, consequentemente, o tempo para se lograr a solução do pleito levado a juízo, o que, de certa forma, estaria contra os objetivos do Novo Código de Processo Civil. ${ }^{80}$

Entretanto, é leviano criticar essa suposta mora processual em razão da nova contagem dos prazos processuais. Verdade seja dita, levantar o argumento de que o processo terá o seu tempo de duração aumentado de maneira insensata, unicamente por causa de uma alteração no cômputo dos prazos, é ignorar muitos problemas que já assolavam o processo judicial brasileiro antes da vigência do Novo CPC.

Por certo, podem ser citados alguns motivos que integram uma vultosa lista de óbices que levam a um procedimento moroso e em desacordo com os preceitos constitucionais da celeridade e duração razoável do processo: o alto número de ações ajuizadas diariamente, o que avoluma sobremaneira o trabalho dos juízes e servidores da justiça; ${ }^{81}$ a carência de pessoal qualificado nos cartórios judiciais, principalmente na área administrativa; ${ }^{82}$ os excessos realizados pelas partes e advogados; a prática de atos e diligências inúteis para a solução do processo; o enorme formalismo e afastamento da simplicidade, problema que afeta muitos juízes e advogados; entre outras causas de morosidade.

A existência dos chamados "tempos mortos do processo", ${ }^{83}$ períodos de espera entre a prática dos atos processuais, é só mais um dos fatores que concorrem para a lentidão na prestação jurisdicional. Ao jogar a culpa da morosidade procedimental sobre a regra de contagem dos prazos, está-se isentando todo um sistema estatal burocrático, ultrapassado e com poucas perspectivas de melhora.

\footnotetext{
${ }^{80} \mathrm{CPC} / 2015$ - "Art. $4^{\circ}$. As partes têm o direito de obter em prazo razoável a solução integral do mérito, incluída a atividade satisfativa." (BRASIL. Lei no 13.105/2015, de 16 de março de 2015. Diário Oficial da República Federativa. Brasília, DF, 16 de março de 2015. Disponível em: <http://www.planalto.gov.br/ccivil_03/_Ato2015-2018/2015/Lei/L13105.htm>. Acesso em: 11 de março de 2016).

${ }^{81}$ SOUZA, Marcel Brasil. Cômputo dos prazos. In: CRUZ E TUCCI, José Rogério. Coleção repercussões do Novo CPC: Advocacia. Coordenador José Rogério Cruz e Tucci. Salvador : Juspodivm, 2015. 2 v. p. 34-40.

${ }^{82}$ Ibidem.

${ }^{83}$ NEVES, Daniel Amorim Assumpção. Manual de direito processual civil. 8 ed. Salvador : Ed. Juspodivm, 2016. p. 359.
} 
Com efeito, o teor do artigo 219 do Novo Código de Processo Civil é uma gloriosa obtenção para o processo civil brasileiro, pois não apenas o advogado, mas todos os integrantes da relação processual são beneficiados pela contagem dos prazos processuais apenas em dias úteis. Seguindo esse entendimento, denota-se que a modificação trazida pelo Novo CPC é direcionada também aos jurisdicionados. ${ }^{84}$

Vale a pena rememorar que os prazos só serão contados em dias úteis quando conservarem natureza processual, contribuindo para o avançar do procedimento. Nessa esteira, os prazos materiais, que têm por objeto as relações jurídicas atinentes aos bens e utilidades da vida, ${ }^{85}$ não serão contados conforme o NCPC.

Por conseguinte, o quadro trazido pelo artigo 523 do $\mathrm{CPC},{ }^{86}$ referente ao cumprimento de sentença direcionado à satisfação de obrigações de pagar quantia certa, demanda comentários, sendo imperioso ter conhecimento de como deve ser disciplinada a contagem do prazo para o pagamento da obrigação, porque há incerteza quanto à sua natureza. ${ }^{87}$

Daniel Amorim Neves diz que se trata de um prazo material, visto que é um ato que deve ser executado pela parte, sem qualquer caráter postulatório. ${ }^{88}$ Adotando posição diversa, Scarpinella Bueno compreende tal prazo como sendo de direito processual, compreendendo que o pagamento da dívida afeiçoa-se como uma das etapas do cumprimento de sentença, ${ }^{89}$

\footnotetext{
${ }^{84}$ SOUZA, op. cit.

${ }^{85}$ CINTRA, Antônio Carlos de Araújo; DINAMARCO, Cândido Rangel; GRINOVER, Ada Pellegrini. Teoria Geral do Processo. $26^{a}$ ed. rev. e atual. São Paulo : Malheiros Editores, 2010. p. 46.

${ }^{86} \mathrm{CPC} / 2015$ " Art. 523. No caso de condenação em quantia certa, ou já fixada em liquidação, e no caso de decisão sobre parcela incontroversa, o cumprimento definitivo da sentença far-se-á a requerimento do exequente, sendo o executado intimado para pagar o débito, no prazo de 15 (quinze) dias, acrescido de custas, se houver.§ 1o Não ocorrendo pagamento voluntário no prazo do caput, o débito será acrescido de multa de dez por cento e, também, de honorários de advogado de dez por cento.§ 2o Efetuado o pagamento parcial no prazo previsto no caput, a multa e os honorários previstos no § 1o incidirão sobre o restante. 30 Não efetuado tempestivamente o pagamento voluntário, será expedido, desde logo, mandado de penhora e avaliação, seguindo-se os atos de expropriação.” (BRASIL. Lei $\mathrm{n}^{\circ}$ 13.105/2015, de 16 de março de 2015. Diário Oficial da República Federativa. Brasília, DF, 16 de março de 2015. Disponível em: <http://www.planalto.gov.br/ccivil_03/_Ato2015-2018/2015/Lei/L13105.htm>. Acesso em: 11 de março de 2016).

${ }^{87}$ GARUTTI, Bruno Fernando. A incerteza do cômputo dos prazos no cumprimento definitivo de sentença à luz da interpretação do artigo $\mathbf{5 2 3}$ do novo código de processo. 2016. Disponível em <http://www.migalhas.com.br/dePeso/16,MI243454,21048-

A+incerteza+do+computo+dos+prazos+no+cumprimento+definitivo+de> Acesso em 18 de outubro de 2016.

${ }^{88}$ NEVES, Daniel Amorim Assumpção. Manual de direito processual civil. 8 ed. Salvador : Ed. Juspodivm, 2016. p. 1124.

${ }^{89}$ BUENO, Cassio Scarpinella. Manual de direito processual civil: inteiramente estruturado à luz do novo CPC, de acordo com a Lei n. 13.256, de 4-2-2016. 2 ed. rev., atual. e ampl. São Paulo : Saraiva, 2016. p. 445.
} 
uma vez que o executado está obedecendo à ordem de pagamento estabelecida pelo juízo, que inclusive é embutida de multa de $10 \%$ (dez por cento) para o caso de descumprimento.

A segunda acepção parece solucionar melhor a interrogação, mormente porque o ato do pagamento advém de um comando proferido pela autoridade judiciária, o que lhe confere, logicamente, caráter coercitivo. ${ }^{90}$ À vista disso, denota-se que o pagamento da dívida (ou inadimplemento) pelo executado afeta o procedimento do cumprimento de sentença, com consequências diretas no processo, ${ }^{91}$ apresentando-se, portanto, como ato processual, que tem seu prazo computado conforme dispõe o artigo 219 do CPC.

O direito intertemporal, do mesmo modo, é digno de comentários, dado que interveio diretamente na aplicação da nova regra de contagem dos prazos. Forte no artigo 14 do Código de Processo Civil, ${ }^{92}$ as normas processuais serão aplicadas imediatamente aos processos em curso e não irão retroagir, respeitando, porém, os atos processuais e situações jurídicas que tenham sido levadas a efeito no período de vigência da Carta Processual revogada, objetivando claramente evitar que as partes sejam surpreendidas com o novo regramento. ${ }^{93}$

Observe-se que essa regra busca preservar o ato jurídico perfeito e o direito adquirido, ${ }^{94}$ estando amoldada ao artigo $5^{\circ}$, inciso XXXVI, da Carta Maior, ${ }^{95}$ e também ao

\footnotetext{
${ }^{90}$ WAMBIER, Teresa Arruda Alvim Wambier. et. al. Primeiros comentários ao novo código de processo civil: artigo por artigo. Coordenação Teresa Arruda Alvim Wambier... [et al.]. 1 ed. São Paulo : Revista dos Tribunais, 2015. p. 867.

${ }^{91}$ DELLORE, Luiz. Novo CPC: o prazo para pagamento é em dias úteis ou corridos no cumprimento de sentença e execução? 2016. Disponível em <http://jota.info/no-cumprimento-de-sentenca-e-execucao-no-novocpc-o-prazo-para-pagamento-e-em-dias-uteis-ou-corridos> Acesso em 18 de outubro de 2016.

${ }^{92} \mathrm{CPC} / 2015$ - "Art. 14. A norma processual não retroagirá e será aplicável imediatamente aos processos em curso, respeitados os atos processuais praticados e as situações jurídicas consolidadas sob a vigência da norma revogada." (BRASIL. Lei no 13.105/2015, de 16 de março de 2015. Diário Oficial da República Federativa. Brasília, DF, 16 de março de 2015. Disponível em: <http://www.planalto.gov.br/ccivil_03/_Ato20152018/2015/Lei/L13105.htm>. Acesso em: 11 de março de 2016).

${ }^{93}$ WAMBIER, Teresa Arruda Alvim Wambier. et. al. Primeiros comentários ao novo código de processo civil : artigo por artigo. Coordenação Teresa Arruda Alvim Wambier... [et al.]. 1 ed. São Paulo : Revista dos Tribunais, 2015. p. 74.

${ }^{94}$ BUENO, Cassio Scarpinella. Manual de direito processual civil : inteiramente estruturado à luz do novo CPC, de acordo com a Lei n. 13.256, de 4-2-2016. 2 ed. rev., atual. e ampl. São Paulo : Saraiva, 2016. p. 104.

${ }^{95} \mathrm{CF} / 88$ - "Art. $5^{\circ}$ Todos são iguais perante a lei, sem distinção de qualquer natureza, garantindo-se aos brasileiros e aos estrangeiros residentes no País a inviolabilidade do direito à vida, à liberdade, à igualdade, à segurança e à propriedade, nos termos seguintes: [...]XXXVI - a lei não prejudicará o direito adquirido, o ato jurídico perfeito e a coisa julgada; [...]"(BRASIL. Constituição da República Federativa do Brasil. Diário Oficial da República Federativa. Brasília, DF, 05 de outubro de 1988. Disponível em: <http://www.planalto.gov.br/ccivil_03/leis/constituicao/constituicaocompilado〉. Acesso em: 25 de setembro de 2016).
} 
artigo $6^{\circ}$ do Decreto-Lei n 4657/42 ${ }^{96}$ (Lei de Introdução às Normas de Direito Brasileiro). À vista disso, a regra de contagem do Novo Código só tem aplicação aos prazos iniciados durante sua vigência, ou seja, no dia 18 de março de 2016.

\subsection{Processo do Trabalho}

Paira a dúvida de como serão aplicados e contados os prazos processuais no Processo do Trabalho após a vigência da Lei 13.105/2015. O questionamento surge em razão de a Consolidação das Leis do Trabalho apresentar diversas lacunas legais quanto às questões processuais, seja por omissão legislativa, seja pela natural superveniência de novas leis atinentes às matérias, pois o regramento contido na CLT é datado de 1943, sendo natural a dificuldade de adaptação de certas normas à realidade social e processual vividas atualmente.

Desse modo, para possibilitar que o processo do trabalho cumpra os requisitos constitucionais, mantendo, assim, observância ao princípio do Devido Processo Legal e aos demais princípios de natureza processual, a própria CLT dispõe que, havendo omissão na legislação trabalhista, é possível a invocação da legislação processual comum, ${ }^{97}$ conforme disposto no seu artigo $769 .^{98}$

O remédio criado pela CLT para "curar" as suas próprias mazelas demonstra que o Processo do Trabalho não pode ser concebido como um ramo autônomo do direito. ${ }^{99}$ Some-se

\footnotetext{
${ }^{96} \mathrm{DL} \mathrm{n}{ }^{\circ} 4657 / 42$ - "Art. $6^{\circ}$ A Lei em vigor terá efeito imediato e geral, respeitados o ato jurídico perfeito, o direito adquirido e a coisa julgada. $\S 1^{\circ}$ Reputa-se ato jurídico perfeito o já consumado segundo a lei vigente ao tempo em que se efetuou. $\S 2^{\circ}$ Consideram-se adquiridos assim os direitos que o seu titular, ou alguém por êle, possa exercer, como aquêles cujo comêço do exercício tenha têrmo pré-fixo, ou condição pré-estabelecida inalterável, a arbítrio de outrem. (BRASIL. Decreto-Lei n ${ }^{\circ} 4.657 / 1942$, de 4 de setembro de 1942. Lei de Introdução às Normas do Direito Brasileiro. Diário Oficial da República Federativa. Rio de Janeiro, RJ, 4 de setembro de 1942. Disponível em: <http://www.planalto.gov.br/ccivil_03/decreto-lei/Del4657compilado.htm>. Acesso em: 25 de setembro de 2016).

97 Valentin Carrion explica essa ligação entre o Direito Processual Civil e o Processo Trabalhista da seguinte maneira: "Assim, do ponto de vista jurídico, a afinidade do direito processual do trabalho com o direito processual comum (civil, em sentido lato) é muito maior (de filho para pai) do que com o direito do trabalho (que é objeto de sua aplicação)." (CARRION, Valentin. Comentários à consolidação das leis do trabalho. 35. ed. atual. Por Eduardo Carrion. São Paulo : Saraiva, 2010. p. 640).

${ }^{98}$ CLT “Art. 769 - Nos casos omissos, o direito processual comum será fonte subsidiária do direito processual do trabalho, exceto naquilo em que for incompatível com as normas deste Título." (BRASIL. Decreto-Lei ${ }^{\circ}$ 5.452/1943, de $1^{\circ}$ de maio de 1943. Aprova a Consolidação das Leis do Trabalho. Diário Oficial da República Federativa. Rio de Janeiro, RJ, $1^{\circ}$ de maio de 1943. Disponível em: <http://www.planalto.gov.br/ccivil_03/decreto-lei/Del5452.htm>. Acesso em: 10 de abril de 2016).

99 MEIRELES, Edilton. O novo CPC e sua aplicação supletiva e subsidiária no processo do trabalho. In: BRANDÃO, Cláudio; MALLET, Estêvão. Coleção repercussões do novo CPC: Processo do Trabalho.
} 
a isso o fato de que o artigo 15 do Código de Processo Civil prescreve que as normas processuais civis possuem aplicação nos processos trabalhistas, desde que de forma supletiva e subsidiária. ${ }^{100}$

A propósito, essa visão de total autonomia do processo do trabalho, apresentada por alguns doutrinadores da área trabalhista, vai contra as tendências do Direito moderno, pois o processo deve estar inevitavelmente alinhavado à integralidade do sistema jurídico-legal pátrio. ${ }^{101}$ Por conseguinte, existindo omissão na CLT, a legislação processual comum será a responsável por preencher a lacuna legal respectiva, desde que se mostre compatível com os princípios e regramentos do Direito Laboral. ${ }^{102}$

Forçoso dizer que não houve a revogação do artigo 769 da CLT pelo artigo 15 do CPC, seja de forma tácita, seja de forma expressa, visto que para que a lei nova possa modificar ou revogar lei anterior é indispensável que isso se dê mediante uma das seguintes situações: a) quando há declaração expressa da revogação no texto legal; b) quando se verifica incompatibilidade entre as normas; c) quando a lei nova regulamentar de forma completa a matéria de que trata a lei anterior. ${ }^{103} \mathrm{Na}$ situação apresentada não se constata a presença de qualquer indício que possa dar azo ao entendimento de que a cláusula trabalhista tenha sido revogada, já que a disposição processual civil apenas preceitua regra a par da já existente, estando em total consonância com a lei anterior. ${ }^{104}$

Com efeito, a aplicação supletiva da norma processual civil no processo do trabalho se dará quando houver omissão legal na CLT sobre ponto do procedimento, ${ }^{105}$ servindo como

Coordenadores Cláudio Brandão e Estêvão Mallet. $2^{\circ}$ ed. rev. e atual. Salvador : Juspodivm, 2016. 4 v. p. $87-$ 111.

${ }^{100} \mathrm{CPC} / 2015$ "Art. 15. Na ausência de normas que regulem processos eleitorais, trabalhistas ou administrativos, as disposições deste Código lhes serão aplicadas supletiva e subsidiariamente." (BRASIL. Lei n ${ }^{\circ}$ 13.105/2015, de 16 de março de 2015. Diário Oficial da República Federativa. Brasília, DF, 16 de março de 2015. Disponível em: <http://www.planalto.gov.br/ccivil_03/_Ato2015-2018/2015/Lei/L13105.htm>. Acesso em: 11 de março de 2016).

${ }^{101}$ DIDIER Jr., Fredie. Curso de direito processual civil: introdução ao direito processual civil, parte geral e processo de conhecimento. 17 ed. Salvador : Ed. Jus Podivm, 2015. p. 63.

102 MARTINS, Sergio Pinto. Direito processual do trabalho: doutrina e prática forense; modelos de petições, recursos, sentenças e outros. 32. ed. São Paulo : Atlas, 2011. p. 27 e 35.

${ }^{103}$ TARTUCE, Flávio. Manual de direito civil. 6. ed. rev., atual. e ampl. - Rio de Janeiro: Forense; São Paulo: MÉTODO, 2016. p. 06

${ }^{104}$ Ibidem.

${ }^{105}$ MIRANDA, Flávia Poyares; FREIRE, Alexandre Reis Siqueira; SCHMITZ, Leonard Ziesemer. Da aplicação das normas processuais. In: ALVIM, Angélica Arruda. et. al. Comentários ao código de processo civil. Coordenadores Angélica Arruda Alvim... [et. al.] 1 ed. São Paulo : Saraiva, 2016. p. 71-75. 
um complemento, uma forma de suprir a lacuna existente. ${ }^{106}$ De outra banda, a aplicação subsidiária do CPC será levada a efeito quando for necessário adequar o conteúdo da norma trabalhista à realidade, perfectibilizando o seu resultado $^{107}$ e melhorando a sua compreensão. $^{108}$

Todavia, a CLT, em seu artigo 775, preceitua que os prazos processuais devem ser computados de forma contínua, ${ }^{109}$ não importando se durante o decorrer do lapso temporal para a realização do ato venham a ocorrer feriados ou dias sem expediente forense, apenas mantendo a regra processual de considerar o dies a quo ou o dies ad quem unicamente em dias úteis.

A celeuma, nesta situação, decorre da existência de lei nova alterando a contagem dos prazos processuais. O regramento processual civil determina, em seu artigo 219, a contagem dos prazos processuais considerando unicamente os dias úteis, com expediente forense. A norma em comento pronuncia-se como passível de aproveitamento pelo Processo do Trabalho, contribuindo na obtenção de um processo mais justo, além de não influir negativamente na celeridade e duração razoável do processo. ${ }^{110}$

Então, existem duas regras que poderiam ser aplicadas quanto à contagem dos prazos processuais, uma que aduz que na contagem em dias serão computados apenas os dias úteis e outra que dispõe no sentido da contagem de forma contínua, não excluindo os dias considerados não úteis. Assim, qual das duas regras deve ser seguida durante o trâmite do processo trabalhista? A resposta é entregue pelo Tribunal Superior do Trabalho.

\footnotetext{
${ }^{106}$ BUENO, Cassio Scarpinella. Manual de direito processual civil: inteiramente estruturado à luz do novo CPC, de acordo com a Lei n. 13.256, de 4-2-2016. 2 ed. rev., atual. e ampl. São Paulo : Saraiva, 2016. 106.

${ }^{107}$ MIRANDA, Flávia Poyares; FREIRE, Alexandre Reis Siqueira; SCHMITZ, Leonard Ziesemer. Da aplicação das normas processuais. In: ALVIM, Angélica Arruda. et. al. Comentários ao código de processo civil. Coordenadores Angélica Arruda Alvim... [et. al.] 1 ed. São Paulo : Saraiva, 2016. p. 71-75.

${ }^{108}$ BUENO, Cassio Scarpinella. Manual de direito processual civil: inteiramente estruturado à luz do novo CPC, de acordo com a Lei n. 13.256, de 4-2-2016. 2 ed. rev., atual. e ampl. São Paulo : Saraiva, 2016. 106.

${ }^{109}$ CLT “ Art. 775 - Os prazos estabelecidos neste Título contam-se com exclusão do dia do começo e inclusão do dia do vencimento, e são contínuos e irreleváveis, podendo, entretanto, ser prorrogados pelo tempo estritamente necessário pelo juiz ou tribunal, ou em virtude de força maior, devidamente comprovada. Parágrafo único - Os prazos que se vencerem em sábado, domingo ou dia feriado, terminarão no primeiro dia útil seguinte." (BRASIL. Decreto-Lei ${ }^{\circ} 5.452 / 1943$, de $1^{\circ}$ de maio de 1943. Aprova a Consolidação das Leis do Trabalho. Diário Oficial da República Federativa. Rio de Janeiro, RJ, $1^{\circ}$ de maio de 1943. Disponível em: <http://www.planalto.gov.br/ccivil_03/decreto-lei/Del5452.htm>. Acesso em: 10 de abril de 2016).

110 TUPINAMBÁ, Carolina. O processo do trabalho e os novos prazos processuais do CPC/2015. In: BRANDÃO, Cláudio; MALLET, Estêvão. Coleção repercussões do novo CPC: Processo do Trabalho. Coordenadores Cláudio Brandão e Estêvão Mallet. $2^{\circ}$ ed. rev. e atual. Salvador : Juspodivm, 2016. 2 v. p. 247283.
} 
Prevendo a possibilidade de divergências doutrinárias, jurisprudenciais e acadêmicas, o TST concebeu a Instrução Normativa $n^{\circ}$ 39/2016, documento que visa regulamentar e estipular os limites da aplicabilidade do Novo Código de Processo Civil ao Processo do Trabalho.

Destarte, o artigo $2^{\circ}$, inciso III, da referida Instrução Normativa, é sucinto e direto ao referir que não há aplicabilidade do artigo 219 do Novo CPC ao Processo do Trabalho, porque não se verifica qualquer omissão na CLT que autorize a sua utilização, sendo o dispositivo incompatível com a norma trabalhista. ${ }^{111}$

Fica, então, afastada a possibilidade, ao menos por enquanto, de que a contagem dos prazos se dê na forma expressa pelo Código de Processo Civil quando tratar-se de Processo Trabalhista, haja vista que este seguirá os ditames do artigo 775 da CLT. Importante mencionar que a Instrução Normativa ${ }^{\circ} 39$ do TST não vincula, mas orienta a atuação dos Órgãos Julgadores de instâncias inferiores quanto à aplicação do Novo CPC.

\subsection{Sistema dos Juizados Especiais}

A discussão referente à aplicabilidade das disposições contidas do Diploma Processual aos processos dos Juizados Especiais tomou força com a proximidade da entrada em vigor do Novo Código de Processo Civil.

De início, é primordial assinalar que ao tratar sobre os Juizados Especiais, há três legislações regulamentando a matéria: Lei n 9099/1995, que instituiu os Juizados Especiais Cíveis e Criminais, Lei $n^{\circ} 10.259 / 2001$, que instituiu os Juizados Especiais Federais e Lei $n^{\circ}$ 12.153/2009, que instituiu os Juizados da Fazenda Pública. São essas três legislações que integram o Sistema dos Juizados Especiais.

Conquanto sejam responsáveis por reger o procedimento adotado nos feitos de competência dos Juizados Especiais, as legislações pertinentes não prescrevem norma referente ao modo de contagem que será adotado. Dito isso, durante o período de vigência do

\footnotetext{
${ }^{111}$ Instrução Normativa $n^{\circ} 39$ do TST “Art. $2^{\circ}$ Sem prejuízo de outros, não se aplicam ao Processo do Trabalho, em razão de inexistência de omissão ou por incompatibilidade, os seguintes preceitos do Código de Processo Civil: III - art. 219 (contagem de prazos em dias úteis);”. (BRASIL. Tribunal Superior do Trabalho. Instrução Normativa $\mathbf{n}^{\circ} 39$ do Tribunal Superior do Trabalho. Dispõe sobre as normas do Código de Processo Civil de 2015 aplicáveis e inaplicáveis ao Processo do Trabalho, de forma não exaustiva. 15 de março de 2016. Disponível em: <http://www.tst.jus.br/documents/10157/429ac88e-9b78-41e5-ae28-2a5f8a27f1fe> Acesso em: 10 de abril de 2016).
} 
Código de Processo de Civil de 1973, os Juizados Especiais aproveitavam-se do comando expresso no artigo 178 da legislação revogada, consagrando a contagem dos prazos na forma corrida. $^{112}$

Com a revogação do CPC/73 pelo CPC/15, aparentava ser lógica - e pacífica - a aplicação do artigo 219 nos processos dos Juizados, justamente em razão da omissão existente nas legislações que lhe são inerentes. Entretanto, o que se avista é uma enorme divergência quanto à matéria, com exceção, porém, às causas de natureza criminal que são processadas perante os Juizados Especiais, nas quais é empregado o artigo 798, caput, do Código de Processo Penal, que prevê a contagem dos prazos de forma contínua. ${ }^{113}$

No contexto dos Juizados Especiais Federais, o Fórum Nacional dos Juizados Especiais Federais (FONAJEF) abraçou a regra de contagem do CPC ao criar o Enunciado de $\mathrm{n}^{\circ} 175$, que, baseado na omissão legislativa existente na Lei $\mathrm{n}^{\circ} 10.259 / 2001$, reconhece a aplicação do artigo 219 da Carta Processual Cível aos processos nos JEF’s. ${ }^{114}$

Os Juizados Especiais Cíveis e os Juizados da Fazenda Pública não possuem a mesma sorte, uma vez que estão muito distantes de um entendimento homogêneo. Isso porque é verificada uma dicotomia no que concerne à possibilidade de aplicação do artigo 219 do Novo CPC aos Juizados Especiais, o que será exposto a seguir.

A Escola Nacional de Formação e Aperfeiçoamento de Magistrados (Enfam) emitiu, em setembro de 2015, 62 (sessenta e dois) enunciados tratando sobre o Novo Código de Processo Civil, entabulando, no Enunciado $\mathrm{n}^{\circ} 45,{ }^{115}$ o entendimento de que é plenamente

\footnotetext{
${ }^{112}$ MANUCCI, Renato Pessoa. Não há incompatibilidade na contagem de prazos em dias úteis nos Juizados Especiais. 2016. Disponível em <https://jus.com.br/artigos/49231/nao-ha-incompatibilidade-na-contagem-deprazos-em-dias-uteis-nos-juizados-especiais> Acesso em 05 de novembro de 2016.

${ }^{113}$ CPP/41 "Art. 798. Todos os prazos correrão em cartório e serão contínuos e peremptórios, não se interrompendo por férias, domingo ou dia feriado. [...]" (BRASIL. Decreto-Lei $\mathrm{n}^{\circ}$ 3.689/41, de 03 de outubro de 1941. Código de Processo Penal. Diário Oficial da República Federativa. Rio de Janeiro, RJ, 03 de outubro de 1941. Disponível em: <http://www.planalto.gov.br/ccivil_03/decreto-lei/Del3689Compilado.htm>. Acesso em: 05 de novembro de 2016).

${ }^{114}$ FORUM NACIONAL DOS JUIZADOS ESPECIAIS FEDERAIS. Enunciado no 175. "Por falta de previsão legal específica nas leis que tratam dos juizados especiais, aplica-se, nestes, a previsão da contagem dos prazos em dias úteis (CPC/2015, art. 219) (Aprovado no XIII FONAJEF).”. Disponível em <http://www.ajufe.org/static/ajufe/arquivos/downloads/fonajef-enunciados-compilados-i-ao-xiii-definitivo1151152.pdf> Acesso em: 15 de outubro de 2016.

${ }^{115}$ ESCOLA NACIONAL DE FORMAÇÃO E APERFEIÇOAMENTO DE MAGISTRADOS. Enfam divulga 62 enunciados sobre a aplicação do novo CPC. 01 de setembro de 2015. Disponível em <http://www.enfam.jus.br/2015/09/enfam-divulga-62-enunciados-sobre-a-aplicacao-do-novo-cpc/> Acesso em: 26 de maio de 2016
} 
aplicável o conteúdo do artigo 219 do CPC aos Juizados Especiais Cíveis e da Fazenda Pública. ${ }^{116}$

Uma opinião consonante à do ENFAM foi emitida pelo Fórum Permanente de Processualistas Civis, que, em encontro realizado em abril de 2015, redigiram os Enunciados $\mathrm{n}^{\circ} 415^{117}$ e $\mathrm{n}^{\circ} 416,{ }^{118}$ reconhecendo a forma de contagem apresentada pelo Novo CPC como aplicável à totalidade do Sistema dos Juizados Especiais.

Em contrapartida, o Fórum Nacional de Juizados Especiais (FONAJE), durante reunião realizada na cidade de Florianópolis/SC, emitiu, no dia 04 de março de 2016, a Nota Técnica de $\mathrm{n}^{\circ} 01$ de 2016, na qual está inserido o entendimento de que a contagem de prazos processuais apenas considerando os dias úteis, conforme o artigo 219 do Novo CPC, não é compatível com o procedimento dos Juizados Especiais Cíveis. ${ }^{119}$

Explicando o motivo da recusa na aplicação da norma processual em questão, argumenta o FONAJE que há uma violação aos princípios da razoável duração do processo e da celeridade, alicerces informativos dos Juizados Especiais Cíveis, bem como o fato de a Lei 9.099/95 ter caráter especial, o que a sobrepõe em relação ao Código de Processo Civil. O parecer do FONAJE fora aplaudido pela atual corregedora nacional de justiça, Ministra Nancy Andrighi, que concorda totalmente com o exposto na Nota Técnica 01/2016. ${ }^{120}$

Durante o $71^{\circ}$ encontro do Colégio Permanente de Corregedores-Gerais de Justiça do Brasil (ENCOJE), ocorrido no Mato Grosso entre 30 de Março e $1^{\circ}$ de Abril, foi elaborada a Carta de Cuiabá, documento fortemente influenciado pela Nota Técnica $n^{\circ}$ 01/2016, do FONAJE. A segunda conclusão formulada no referido escrito repete a convicção do FONAJE

\footnotetext{
${ }^{116}$ Idem. Enunciado no 45. "A contagem dos prazos em dias úteis (art. 219 do CPC/2015) aplica-se ao sistema de juizados especiais.". Disponível em <http://www.enfam.jus.br/wp-content/uploads/2015/09/ENUNCIADOSVERSAO-DEFINITIVA-.pdf> Acesso em: 26 de maio de 2016.

${ }^{117}$ FORUM PERMANENTE DE PROCESSUALISTAS CIVIS. Enunciado n ${ }^{\circ}$ 415. “(arts. 212 e 219; Lei 9.099/1995, Lei 10.259/2001, Lei 12.153/2009) Os prazos processuais no sistema dos Juizados Especiais são contados em dias úteis. (Grupo:Impacto nos Juizados e nos procedimentos especiais da legislação extravagante)". Disponível em <http://portalprocessual.com/wp-content/uploads/2016/05/Carta-de-S\%C3\%A3oPaulo.pdf > Acesso em: 15 de outubro de 2016.

${ }^{118}$ Idem. Enunciado $\mathbf{n}^{\circ}$ 416. "(art. 219) A contagem do prazo processual em dias úteis prevista no art. 219 aplica-se aos Juizados Especiais Cíveis, Federais e da Fazenda Pública. (Grupo: Impacto do novo CPC e os processos da Fazenda Pública)" Disponível em < http://portalprocessual.com/wp-content/uploads/2016/05/Cartade-S\%C3\%A3o-Paulo.pdf> Acesso em: 15 de outubro de 2016.

${ }^{119}$ FORUM NACIONAL DOS JUÍZADOS ESTADUAIS. FONAJE lança Nota Técnica sobre Artigo 219 do novo CPC. 14 de março de 2016. Disponível em <http://www.amb.com.br/fonaje/?p=610> Acesso em: 26 de maio de 2016.

${ }^{120}$ BRASIL. Conselho Nacional de Justiça. Prazos do novo CPC não devem valer para os Juizados Especiais. Disponível em <http://www.cnj.jus.br/noticias/cnj/81833-corregedoria-prazos-do-novo-cpc-naovalem-para-os-juizados-especiais>. Acesso em 12 de Outubro de 2016.
} 
e da Corregedora Nacional de Justiça, expondo que os prazos processuais devem ser computados de forma corrida nos Juizados Especiais. ${ }^{121}$

A firmeza do posicionamento defendido pelo FONAJE acarretou na elevação do status da Nota Técnica $n^{\circ}$ 01/2016, o que se deu mediante a concepção de dois enunciados: o Enunciado da Fazenda Pública ${ }^{\circ} 13^{122}$ e o Enunciado Cível $n^{\circ} 165,{ }^{123}$ ambos considerando que a contagem dos prazos deve ser feita de forma contínua nos Juizados Especiais.

Nessa perspectiva, determinados Tribunais já manifestaram contrariedade à contagem dos prazos processuais unicamente em dias úteis no âmbito dos Juizados Especiais, o que se verifica em Estados como o Rio de Janeiro, ${ }^{124}$ Maranhão, ${ }^{125}$ São Paulo, Santa Catarina, Pernambuco e Paraná. ${ }^{126}$ De outra banda, aprovam a aplicação do artigo supracitado no sistema dos Juizados Especiais os Estados do Distrito Federal, ${ }^{127}$, Tocantins, ${ }^{128}$ Amazonas e Minas Gerais, entre outros.

121 ENCOGE. $\mathbf{7 1}^{\mathbf{0}}$ ENCOGE termina com publicação da Carta de Cuiabá. Disponível em http://71encoge.tjmt.jus.br/noticia/24/71-encoge-termina-com-publicacao-da-carta-de-cuiaba Acesso em 12 de outubro de 2016.

${ }^{122}$ FORUM NACIONAL DOS JUIZADOS ESPECIAIS. Enunciado da Fazenda Pública n ${ }^{\circ}$ 13. "A contagem dos prazos processuais nos Juizados da Fazenda Pública será feita de forma contínua, observando-se, inclusive, a regra especial de que não há prazo diferenciado para a Fazenda Pública - art. $7^{\circ}$ da Lei 12.153/09.”. Disponível em <http://www.amb.com.br/fonaje/?p=32> Acesso em: 12 de outubro de 2016.

${ }^{123}$ Idem. Enunciado Cível $\mathbf{n}^{\circ} \mathbf{1 6 5}$. "Nos Juizados Especiais Cíveis, todos os prazos serão contados de forma contínua.". Disponível em <http://www.amb.com.br/fonaje/?p=32> Acesso em: 12 de outubro de 2016.

${ }^{124}$ RIO DE JANEIRO. Tribunal de Justiça. Enunciado n ${ }^{\circ}$ 12/2016 da Comissão Judiciária de Articulação dos Juizados Especiais - COJES. "PRAZOS - FORMA DE CONTAGEM. Os prazos processuais em sede de Juizados Especiais Cíveis são contados em dias corridos, inaplicável o artigo 219 do Código de Processo Civil de 2015.”. Disponível em 〈http://www.tjrj.jus.br/documents/10136/18972/aviso-conjunto-tj-cojes-15-2016.pdf> Acesso em: 06 de novembro de 2016.

${ }^{125}$ MARANHÃO. Tribunal de Justiça. Turma de Uniformização decide que Juizado Especial não seguirá prazo do novo CPC. Disponível em <http://www.tjma.jus.br/cgj/visualiza/publicacao/412272> Acesso em: 06 de novembro de 2016.

${ }^{126}$ MIGALHAS. Juizados Especiais se dividem entre aplicar ou não contagem de prazos do CPC/15. Disponível em <http://www.migalhas.com.br/Quentes/17,MI237194,101048Juizados+Especiais+se+dividem+entre+aplicar+ou+nao+contagem+de+prazos> 06 de novembro de 2016.

${ }^{127}$ DISTRITO FEDERAL. Tribunal de Justiça. Súmula n $\mathbf{n}^{\circ}$ dos Juizados Especiais. "Nos Juizados Especiais Cíveis e de Fazenda Pública, na contagem de prazo em dias, estabelecido por lei ou pelo juiz, computar-se-ão somente os dias úteis, nos termos do art. 219, do Código de Processo Civil (Lei no 13.105/15).”. Disponível em <http://www.tjdft.jus.br/institucional/jurisprudencia/sumulas-do-juizado-especial> Acesso em: 06 de novembro de 2016.

${ }^{128}$ TOCANTINS. Tribunal de Justiça. Juizados Especiais Cíveis seguirão prazos processuais do novo CPC. Disponível em <http://www.tjto.jus.br/index.php/listagem-noticias/4059-juizados-especiais-civeis-seguiraoprazos-processuais-do-novo-cpc> Acesso em: 06 de novembro de 2016. 
No Tribunal de Justiça do Estado do Rio Grande do Sul foi exarado o Ofício de $\mathrm{n}^{\circ}$ 054/2016 da Corregedoria Geral de Justiça, ${ }^{129}$ documento direcionado aos magistrados que informa sobre a posição das Turmas Recursais no sentido de que há total aplicabilidade do artigo 219 do CPC nos Juizados Especiais, logo, os prazos, nesse âmbito, deverão ser contados considerando apenas os dias úteis.

Tal posicionamento vem sendo adotado pela Corte Gaúcha, destacando-se a decisão da Segunda Turma Recursal Cível do Tribunal de Justiça do Estado do Rio Grande do Sul, na qual foi concedida a ordem em Mandado de Segurança impetrado contra ato judicial que considerou intempestiva a interposição de recurso inominado, tendo em vista que a autoridade coatora optou pela contagem do prazo em dias contínuos, adotando a visão do Código de Processo Civil de 1973, o que não poderia ser sustentado em vista de a sentença ter sido publicada no período de vigência do Novo Código, o que influi na necessidade de realizar a contagem do prazo levando em conta apenas os dias úteis. ${ }^{130}$

Convém dizer que a OAB enviou, em maio de 2016, ofício destinado ao Presidente do Conselho Nacional de Justiça, solicitando um posicionamento e possível regulamentação acerca da matéria inerente a contagem dos prazos processuais, buscando a aplicação do artigo 219 aos processos dos Juizados Especiais e aos Processos do Trabalho, argumentando que a regra não implicará em prejuízos à celeridade processual, princípio norteador desses ramos do direito. $^{131}$

Recorrendo a alguns dos argumentos esposados no ofício enviado ao $\mathrm{CNJ}$, a OAB remeteu, em agosto de 2016, novo ofício, desta vez direcionado ao FONAJE, no qual solicita a adequação dos Enunciados supramencionados, pois não há preceito legal que balize e sustente a contagem dos prazos processuais pela forma contínua. ${ }^{132}$ Não há, entretanto, informação de que algum dos ofícios tenha sido respondido.

${ }^{129}$ RIO GRANDE DO SUL. Tribunal de Justiça. Ofício circular 054/2016 CGJ TJRS. Disponível em: <http://www.tjrs.jus.br/site/imprensa/destaques/doc/2016/OFICIO_CIRCULAR_054_2016_CGJ.pdf> Acesso em: 26 de maio de 2016.

${ }^{130}$ RIO GRANDE DO SUL. Tribunal de Justiça. Segunda Turma Recursal Cível. Mandado de Segurança ${ }^{\circ}$ 71006091029. Comarca de São Leopoldo. Relator: Roberto Behrensdorf Gomes da Silva, 25 mai. 2016. Diário da Justiça, Porto Alegre, 30 mai. 2016.

${ }^{131}$ ORDEM DOS ADVOGADOS DO BRASIL. Ofício 706/2016 - OAB. Brasília, DF, 10 de maio de 2016. Disponível em: <http://s.conjur.com.br/dl/prazo-cpc-oab-cnj.pdf> Acesso em: 26 de maio de 2016.

132 Idem. Ofício 1178/2016 - OAB. Brasília, DF, 08 de agosto de 2016. Disponível em: < http://s.oab.org.br/arquivos/2016/08/oficio-revisao-de-enunciados-dias-uteis-003.pdf> Acesso em: 06 de novembro de 2016. 
Frente aos dissentimentos de interpretação que vem ocorrendo sobre o tema, resta necessária a uniformização da jurisprudência quanto à contagem dos prazos nos Juizados Especiais. É por esse motivo que o CPC, ao incluir em seu texto a necessidade da uniformização da jurisprudência, procura a correção de um problema existente na Jurisdição Brasileira, maculada pelas inúmeras divergências de interpretação dos magistrados, fato que causa insegurança jurídica e instabilidade nas decisões judiciais. ${ }^{133}$

Há, inclusive, a possibilidade de ocorrência de contradições entre turmas, sessões, ou câmaras de um mesmo Tribunal quanto aos julgamentos, fato não raro e que delata a evidente desarmonia jurisprudencial instalada no Brasil. ${ }^{134}$ É aí que se mostra patente a relevância de uma produção jurisprudencial coesa, convergente e sólida, pois irrompe uma garantia de isonomia no tratamento dos sujeitos do processo e eleva a confiança na atuação do Poder Judiciário. $^{135}$

Sendo assim, a consolidação de um entendimento homogêneo quanto à contagem dos prazos no âmbito dos Juizados Especiais favorecerá os Tribunais, advogados e, também, os jurisdicionados, já que a uniformização da jurisprudência promove a diminuição de decisões e processos discordantes, resultando em um engrandecimento da tão almejada segurança jurídica. ${ }^{136}$

\footnotetext{
${ }^{133}$ CPC 2015 "Art. 926. Os tribunais devem uniformizar sua jurisprudência e mantê-la estável, íntegra e coerente. $\S 1$ o $\mathrm{Na}$ forma estabelecida e segundo os pressupostos fixados no regimento interno, os tribunais editarão enunciados de súmula correspondentes a sua jurisprudência dominante. § 20 Ao editar enunciados de súmula, os tribunais devem ater-se às circunstâncias fáticas dos precedentes que motivaram sua criação." (BRASIL. Lei $\mathrm{n}^{\circ}$ 13.105/2015, de 16 de março de 2015. Diário Oficial da República Federativa. Brasília, DF, 16 de março de 2015. Disponível em: <http://www.planalto.gov.br/ccivil_03/_Ato20152018/2015/Lei/L13105.htm>. Acesso em: 11 de março de 2016).

${ }^{134}$ CRUZ E TUCCI, José Rogério. Precedentes judiciais e a atuação do advogado. In: José Rogério. Coleção repercussões do Novo CPC: Advocacia. Coordenador José Rogério Cruz e Tucci. Salvador : Juspodivm, 2015. 2 v. p. 107-117.

${ }^{135}$ GURGEL DE FARIA, Luiz Alberto. Da ordem dos processos e dos processos de competência originária dos Tribunais. In: ALVIM, Angélica Arruda. et. al. Comentários ao código de processo civil. Coordenadores Angélica Arruda Alvim... [et. al.] 1 ed. São Paulo : Saraiva, 2016. p. 1060-1064.

${ }^{136}$ NOGUEIRA. Cláudia Albagli. O Novo Código de Processo Civil e o sistema de precedentes judiciais: pensando um paradigma discursivo da decisão judicial. Revista Brasileira de direto Processual - RBD PRO, Belo Horizonte. ano 22, n. 88. p.185-210, out./dez., 2014.
} 


\section{CONSIDERAÇÕES FINAIS}

Para avolumar o período da realização dos atos processuais, o Código trouxe uma solução mais humanitária, excluindo os sábados, domingos e feriados da contagem. ${ }^{137}$ Considerando apenas os dias úteis no cômputo dos prazos, a legislação provocou uma significativa alteração na sistemática processual brasileira, substituindo o paradigma que era trazido pela Carta Processual Civil de 1973.

Mais tempo significa uma pressão menor sobre os operadores do Direito, o que, por sua vez, possibilita a obtenção de um trabalho de maior qualidade e maior efetividade na prestação jurisdicional. Partindo de uma visão prático jurídica, a disposição contida no artigo 219 do CPC é uma evidente melhoria no processo civil, pois evita a necessidade de realização de atos processuais em dias em que não há expediente forense ou dedicados ao descanso, bem como em período demasiadamente curto. ${ }^{138}$

Permanece inegável a afirmação de que a nova regra causa aumento na dimensão dos prazos processuais, todavia, inexiste espaço para criticar o dispositivo porque esse, em tese, fere a celeridade e duração razoável do processo. Não há motivo para desdenhar da opção do legislador em inserir o artigo 219 no Código de Processo Civil vigente. Na prática, os fatores que ocasionam a demora na resolução dos processos vão muito além de uma modificação na regra da contagem dos prazos processuais.

Não se pode olvidar, também, que o processo judicial apresenta uma relação jurídica trilateral e de direito público, ${ }^{139}$ envolvendo um autor que realiza o pedido, um réu que se defende e um juiz que, representando o Estado, julga a demanda trazida a juízo. ${ }^{140}$ As três figuras citadas são responsáveis por buscar a celeridade e razoável duração do processo, haja vista que o Novo CPC inseriu o princípio e comando de que o processo se desenvolverá a partir da cooperação entre os sujeitos que o integram. ${ }^{141}$

\footnotetext{
${ }^{137}$ PEIXOTO, Ulisses Vieira Moreira. Os prazos no novo código de processo civil. $1^{\text {a }}$ ed. Campo Grande : Contemplar, 2016. p. 24.

${ }^{138}$ FERREIRA, Antônio Oneildo, A advocacia sob uma perspectiva temporal. ORDEM DOS ADVOGADOS DO BRASIL - OAB (org). As conquistas da advocacia no novo CPC. Brasília: OAB, Conselho Federal, 2015. p. 83-101.

139 BUENO, Cassio Scarpinella. Manual de direito processual civil: inteiramente estruturado à luz do novo CPC, de acordo com a Lei n. 13.256, de 4-2-2016. 2 ed. rev., atual. e ampl. São Paulo : Saraiva, 2016. p. 72.

140 MARINONI, Luz Guilherme; ARENHART, Sérgio Cruz; MITIDIERO, Daniel. Novo curso de processo civil: tutela dos direitos mediante procedimento comum. São Paulo: Revista dos Tribunais, 2015. 2 v. p. 71.

141 Ibidem, p.72.
} 
Malgrado a alteração da regra de contagem dos prazos acarretar em benefícios ao procedimento jurisdicional, ainda não há um consenso sobre a sua adoção no âmbito do Processo do Trabalho, dos Juizados Especiais Cíveis e dos Juizados da Fazenda Pública.

Em verdade, a Instrução Normativa $n^{\circ}$ 39/2016 demonstra a assimilação do TST quanto à incompatibilidade da regra de contagem do Código de Processo Civil com o processo trabalhista, uma vez que o artigo 775 da CLT, que estatui o cômputo dos prazos de forma contínua, permanece em plena vigência. A ausência de caráter obrigatório da $\mathrm{IN} \mathrm{n}^{\circ}$ 39/2016 do TST não garante que o entendimento venha a ser adotado por todos os Tribunais Regionais do Trabalho, embora seja muito improvável a resistência à opinião do Tribunal Superior.

Por outro lado, o quadro dos Juizados Especiais demonstra uma grave mazela do Poder Judiciário Brasileiro: a disparidade de pareceres sobre a aplicação de um mesmo artigo de lei. Ao mesmo tempo em que os Juizados Especiais Federais vão convergindo e alcançando uma homogeneidade, há um grande dissenso no cenário dos Juizados Especiais Cíveis e Juizados da Fazenda Pública no tocante à contagem dos prazos processuais.

Como mencionado, o Sistema dos Juizados Especiais é omisso quanto à forma de contagem dos prazos dos processos de sua competência, tendo, em razão disso, sempre adotado a disposição Processual Civil. Esse quadro foi modificado com a vigência do Novo CPC, porque os Tribunais não estão conseguindo encontrar um ponto em comum, abrindo espaço para que cada magistrado aplique a norma da forma que bem entende.

É fato que a discordância entre os Tribunais dá azo aos inúmeros Enunciados proferidos por órgãos não oficiais, mesmo que estes também apresentem diferentes posições sobre a aplicação da regra de contagem nos Juizados Especiais. Com isso, os Tribunais vão, de certa forma, perdendo o controle sobre o procedimento dos Juizados Especiais, visto que a interpretação inicial da lei acaba por ser feita por órgãos como o FONAJE e o ENFAM, por exemplo. Com isso, os magistrados são persuadidos a adotar os Enunciados, caindo numa espécie de zona de conforto interpretativa.

A atuação desses órgãos não oficiais, todavia, é digna de reconhecimento, pois visam padronizar a aplicação das leis processuais, facilitando a atividade jurisdicional. Contudo os pareceres proferidos pelo FONAJE e pelo ENCOGE, que têm servido de influências para alguns Estados, não parecem condizer com a realidade do ordenamento jurídico atual, uma 
vez que, ao optarem pela contagem dos prazos de maneira contínua, estão reconhecendo o artigo 178 do CPC/1973 como válido, praticamente repristinando a legislação revogada, o que só poderia acontecer se adviesse lei que derrogasse o CPC/2015 e, expressamente, autorizasse o retorno do Velho Código à vigência. ${ }^{142}$

Outro problema encontrado é a relutância doutrinária no sentido de abordar com mais profundidade a temática dos prazos processuais. Embora o artigo 219 do CPC seja um dispositivo de palavras simples e relativamente curto, a sua importância é sublime, pois se qualifica como um dos pilares para a construção e desenvolvimento do processo judicial. Além disso, o seu estudo e aplicação, como já discorrido, tem desencadeado diferentes acepções, demonstrando complexidade muito maior do que aparenta ter.

O que se avista com a nova regra de contagem é um dispositivo legal condizente com os objetivos do novo diploma, solidificando uma posição em prol de um processo civil mais humano e de acordo com a realidade social contemporânea. Ademais, os sujeitos do processo precisam se manter atentos à distinção entre a natureza dos prazos materiais, contados de forma contínua, e os prazos processuais, que são computados apenas em dias úteis.

Impende mencionar que o território brasileiro, com suas proporções continentais, necessita de um grande número de magistrados, juízos e tribunais para que a jurisdição possa atingir níveis satisfatórios de efetividade e organização. ${ }^{143}$ Logo, a pertinência da consolidação de um entendimento acerca do alcance do artigo 219 do Código de Processo Civil chega a ser berrante, haja vista que o Poder Judiciário é composto por 91 tribunais, ${ }^{144}$ cada qual com suas competências e peculiaridades, o que torna extremamente perigosa, inclusive para a celeridade processual e razoável duração do processo, a existência de um dissenso generalizado entre os Magistrados quanto à contagem dos prazos processuais.

\footnotetext{
${ }^{142}$ TARTUCE, Flávio. Manual de direito civil. 6. ed. rev., atual. e ampl. - Rio de Janeiro: Forensie; São Paulo: MÉTODO, 2016. p. 7 e 8.

${ }^{143}$ MARINONI, Luz Guilherme; ARENHART, Sérgio Cruz; MITIDIERO, Daniel. Novo curso de processo civil: tutela dos direitos mediante procedimento comum. São Paulo: Revista dos Tribunais, 2015. 2 v. p. 52.

${ }^{144}$ ALVES DE MELO, André Luís. É preciso reduzir em vez de aumentar o número de tribunais no Brasil. 2016. Disponível em <shttp://www.conjur.com.br/2016-fev-19/andre-melo-precisamos-fechar-tribunais-vezcriar> Acesso em 09 de novembro de 2016.
} 


\section{REFERÊNCIAS}

ACQUAVIVA, Marcus Cláudio. Dicionário Jurídico Brasileiro. 6 ed. São Paulo : Jurídica Brasileira, 1994.

ALVES DE MELO, André Luís. É preciso reduzir em vez de aumentar o número de tribunais no Brasil. 2016. Disponível em <shttp://www.conjur.com.br/2016-fev-19/andremelo-precisamos-fechar-tribunais-vez-criar> Acesso em 09 de novembro de 2016.

ALVIM, Angélica Arruda Alvim; ALVIM, Eduardo Arruda Alvim; PEREIRA FILHO, Benedito Cerezzo. Dos atos das partes. In: ALVIM, Angélica Arruda. et. al. Comentários ao código de processo civil. Coordenadores Angélica Arruda Alvim... [et. al.] 1 ed. São Paulo : Saraiva, 2016. p. 279-281.

ALVIM, Arruda. Manual de direito processual civil: parte geral. 9. ed. rev., atual e ampl. São Paulo : Revista dos Tribunais, 2005. 1 v.

ALVIM, José Eduardo Carreira. Teoria Geral do Processo. 18 ed. Rio de Janeiro: Forense, 2015 .

BRASIL. Conselho Nacional de Justiça. Prazos do novo CPC não devem valer para os Juizados Especiais. Disponível em < http://www.cnj.jus.br/noticias/cnj/81833-corregedoriaprazos-do-novo-cpc-nao-valem-para-os-juizados-especiais>. Acesso em 12 de Outubro de 2016.

Constituição da República Federativa do Brasil. Diário Oficial da República

Federativa. Brasília, DF, 05 de outubro de 1988. Disponível em:

<http://www.planalto.gov.br/ccivil_03/leis/constituicao/constituicaocompilado>. Acesso em: 25 de setembro de 2016.

Decreto-Lei n 4.657/1942, de 4 de setembro de 1942. Lei de Introdução às Normas do Direito Brasileiro. Diário Oficial da República Federativa. Rio de Janeiro, RJ, 4 de setembro de 1942. Disponível em: <http://www.planalto.gov.br/ccivil_03/decretolei/Del4657compilado.htm>. Acesso em: 25 de setembro de 2016.

Decreto-Lei $n^{\circ} 5.452 / 1943$, de $1^{\circ}$ de maio de 1943. Aprova a Consolidação das Leis do Trabalho. Diário Oficial da República Federativa. Rio de Janeiro, RJ, $1^{\circ}$ de maio de 1943. Disponível em: <http://www.planalto.gov.br/ccivil_03/decreto-lei/Del5452.htm>. Acesso em: 10 de abril de 2016.

Decreto-Lei no 3.689/41, de 03 de outubro de 1941. Código de Processo Penal. Diário Oficial da República Federativa. Rio de Janeiro, RJ, 03 de outubro de 1941. Disponível em: <http://www.planalto.gov.br/ccivil_03/decreto-lei/Del3689Compilado.htm>. Acesso em: 05 de novembro de 2016. 
Lei no 5.869/73, de 11 de janeiro de 1973. Código de Processo Civil. Diário Oficial da República Federativa. Brasília, DF, 11 de janeiro de 1973. Disponível em: <http://www.planalto.gov.br/ccivil_03/leis/L5869.htm>. Acesso em: 11 de março de 2016.

. Lei n ${ }^{\circ} 13.105 / 2015$, de 16 de março de 2015. Código de Processo Civil. Diário Oficial da República Federativa. Brasília, DF, 16 de março de 2015. Disponível em: <http://www.planalto.gov.br/ccivil_03/_Ato2015-2018/2015/Lei/L13105.htm>. Acesso em: 11 de março de 2016.

Superior Tribunal Federal. Súmula 310. "Quando a intimação tiver lugar na sextafeira, ou a publicação com efeito de intimação for feita nesse dia, o prazo judicial terá início na segunda-feira imediata, salvo se não houver expediente, caso em que começará no primeiro dia útil que se seguir." Disponível em < http://www.stf.jus.br/portal/cms/verTexto.asp?servico=jurisprudenciaSumula\&pagina=sumul a_301_400> Acesso em: 14 de abril de 2016 .

Tribunal Superior do Trabalho. Instrução Normativa $n^{\circ} 39$ do Tribunal Superior do Trabalho. Dispõe sobre as normas do Código de Processo Civil de 2015 aplicáveis e inaplicáveis ao Processo do Trabalho, de forma não exaustiva. 15 de março de 2016. Disponível em: <http://www.tst.jus.br/documents/10157/429ac88e-9b78-41e5-ae282a5f8a27f1 fe> Acesso em: 10 de abril de 2016.

BUENO, Cassio Scarpinella. Manual de direito processual civil: inteiramente estruturado à luz do novo CPC, de acordo com a Lei n. 13.256, de 4-2-2016. 2 ed. rev., atual. e ampl. São Paulo : Saraiva, 2016.

CARRION, Valentin, Comentários à consolidação das leis do trabalho. 35. ed. atual. Por Eduardo Carrion. São Paulo : Saraiva, 2010.

CINTRA, Antônio Carlos de Araújo; DINAMARCO, Cândido Rangel; GRINOVER, Ada Pellegrini. Teoria Geral do Processo. 26 ed. rev. e atual. São Paulo : Malheiros Editores, 2010. p. 46

CRUZ E TUCCI, José Rogério. Precedentes judiciais e a atuação do advogado. In: Coleção repercussões do Novo CPC: Advocacia. Coordenador José Rogério Cruz e Tucci. Salvador: Juspodivm, 2015. 2 v. p. 107-117.

DELLORE, Luiz. Novo CPC: o prazo para pagamento é em dias úteis ou corridos no cumprimento de sentença e execução? 2016. Disponível em <http://jota.info/nocumprimento-de-sentenca-e-execucao-no-novo-cpc-o-prazo-para-pagamento-e-em-dias-uteisou-corridos> Acesso em 18 de outubro de 2016.

DIDIER Jr., Fredie. Curso de direito processual civil: introdução ao direito processual civil, parte geral e processo de conhecimento. 17 ed. Salvador : Ed. Jus Podivm, 2015.

DISTRITO FEDERAL. Tribunal de Justiça. Súmula $\mathbf{n}^{\circ} \mathbf{4}$ dos Juizados Especiais "Nos Juizados Especiais Cíveis e de Fazenda Pública, na contagem de prazo em dias, estabelecido 
por lei ou pelo juiz, computar-se-ão somente os dias úteis, nos termos do art. 219, do Código de Processo Civil (Lei no 13.105/15)." Disponível em

$<$ http://www.tjdft.jus.br/institucional/jurisprudencia/sumulas-do-juizado-especial> Acesso em: 06 de novembro de 2016.

\section{ESCOLA NACIONAL DE FORMAÇÃO E APERFEIÇOAMENTO DE MAGISTRADOS}

Enunciado $\mathbf{n}^{\circ} \mathbf{4 5}$ "A contagem dos prazos em dias úteis (art. 219 do CPC/2015) aplica-se ao sistema de juizados especiais.". Disponível em <http://www.enfam.jus.br/wp-

content/uploads/2015/09/ENUNCIADOS-VERSAO-DEFINITIVA-.pdf> Acesso em: 26 de maio de 2016.

62 enunciados sobre a aplicação do novo CPC disponível em

Enfam divulga

$<$ http://www.enfam.jus.br/2015/09/enfam-divulga-62-enunciados-sobre-a-aplicacao-do-novocpc/> Acesso em: 26 de maio de 2016.

FERREIRA, Antônio Oneildo, A advocacia sob uma perspectiva temporal. ORDEM DOS ADVOGADOS DO BRASIL - OAB (org). As conquistas da advocacia no novo CPC. Brasília: OAB, Conselho Federal, 2015. p. 83-101.

\section{FORUM NACIONAL DOS JUIZADOS ESPECIAIS. Enunciado da Fazenda Pública n ${ }^{\circ}$} 13. “A contagem dos prazos processuais nos Juizados da Fazenda Pública será feita de forma contínua, observando-se, inclusive, a regra especial de que não há prazo diferenciado para a Fazenda Pública - art. $7^{\circ}$ da Lei 12.153/09." Disponível em <http://www.amb.com.br/fonaje/?p=32> Acesso em: 12 de outubro de 2016.

Enunciado Cível n 165. "Nos Juizados

Especiais Cíveis, todos os prazos serão contados de forma contínua.”. Disponível em <http://www.amb.com.br/fonaje/?p=32> Acesso em: 12 de outubro de 2016.

\section{FONAJE lança Nota Técnica sobre}

Artigo 219 do novo CPC. 14 de março de 2016. Disponível em

<http://www.amb.com.br/fonaje/?p=610> Acesso em: 26 de maio de 2016.

FORUM NACIONAL DOS JUIZADOS ESPECIAIS FEDERAIS. Enunciado n 175. " "Por falta de previsão legal específica nas leis que tratam dos juizados especiais, aplica-se, nestes, a previsão da contagem dos prazos em dias úteis (CPC/2015, art. 219) (Aprovado no XIII FONAJEF).”. Disponível em <http://www.ajufe.org/static/ajufe/arquivos/downloads/fonajefenunciados-compilados-i-ao-xiii-definitivo-1151152.pdf> Acesso em: 15 de outubro de 2016.

FORUM PERMANENTE DE PROCESSUALISTAS CIVIS. Enunciado n 415. "(arts. 212 e 219; Lei 9.099/1995, Lei 10.259/2001, Lei 12.153/2009) Os prazos processuais no sistema dos Juizados Especiais são contados em dias úteis. (Grupo:Impacto nos Juizados e nos procedimentos especiais da legislação extravagante)". Disponível em < http://portalprocessual.com/wp-content/uploads/2016/05/Carta-de-S\%C3\%A3o-Paulo.pdf> Acesso em: 15 de outubro de 2016. 
Enunciado n416. “(art. 219) A

contagem do prazo processual em dias úteis prevista no art. 219 aplica-se aos Juizados Especiais Cíveis, Federais e da Fazenda Pública. (Grupo: Impacto do novo CPC e os processos da Fazenda Pública)". Disponível em < http://portalprocessual.com/wpcontent/uploads/2016/05/Carta-de-S\%C3\%A3o-Paulo.pdf> Acesso em: 15 de outubro de 2016.

GARUTTI, Bruno Fernando. A incerteza do cômputo dos prazos no cumprimento definitivo de sentença à luz da interpretação do artigo 523 do novo código de processo. 2016. Disponível em <http://www.migalhas.com.br/dePeso/16,MI243454,21048-

A+incerteza+do+computo+dos+prazos+no+cumprimento+definitivo+de $>$ Acesso em 18 de outubro de 2016.

GRECO FILHO, Vicente. Direito Processual civil brasileiro: (atos processuais a recursos e processos nos tribunais) - 20 ed. rev. e atual. - São Paulo : Saraiva. 2009. 2 v.

GURGEL DE FARIA, Luiz Alberto. Da ordem dos processos e dos processos de competência originária dos Tribunais. In: ALVIM, Angélica Arruda. et. al. Comentários ao código de processo civil. Coordenadores Angélica Arruda Alvim... [et. al.] 1 ed. São Paulo : Saraiva, 2016. p. 1060-1064.

MACEDO, Elaine Harzheim. Comentários aos artigos 218 ao 232. ORDEM DOS ADVOGADOS DO BRASIL - OAB (org). Novo código de processo civil anotado. Porto Alegre : OAB/RS, 2015. p. 192-195.

MANUCCI, Renato Pessoa. Não há incompatibilidade na contagem de prazos em dias úteis nos Juizados Especiais. 2016. Disponível em <https://jus.com.br/artigos/49231/nao-haincompatibilidade-na-contagem-de-prazos-em-dias-uteis-nos-juizados-especiais > Acesso em 05 de novembro de 2016.

MARANHÃO. Tribunal de Justiça. Turma de Uniformização decide que Juizado Especial não seguirá prazo do novo CPC. Disponível em

<http://www.tjma.jus.br/cgj/visualiza/publicacao/412272> Acesso em: 06 de novembro de 2016.

MARINONI, Luz Guilherme; ARENHART, Sérgio Cruz; MITIDIERO, Daniel. Novo curso de processo civil: tutela dos direitos mediante procedimento comum. São Paulo: Revista dos Tribunais, 2015. $2 \mathrm{v}$.

MARTINS, Sérgio Pinto. Direito processual do trabalho: doutrina e prática forense; modelos de petições, recursos, sentenças e outros. 32. ed. São Paulo: Atlas, 2011.

MEIRELES, Edilton. O novo CPC e sua aplicação supletiva e subsidiária no processo do trabalho. In: BRANDÃO, Cláudio; MALLET, Estêvão. Coleção repercussões do novo CPC: Processo do Trabalho. Coordenadores Cláudio Brandão e Estêvão Mallet. $2^{\circ}$ ed. rev. e atual. Salvador : Juspodivm, 2016. 4 v. p. 87-111. 
MILHOMENS, Jônatas. Dos prazos e do tempo no Código de processo civil: incluídos comentários aos arts. 154 a 250. Rio de Janeiro : Forense, 1979.

MIRANDA, Flávia Poyares; FREIRE, Alexandre Reis Siqueira; SCHMITZ, Leonard Ziesemer. Da aplicação das normas processuais. In: ALVIM, Angélica Arruda. et. al. Comentários ao código de processo civil. Coordenadores Angélica Arruda Alvim... [et. al.] 1 ed. São Paulo : Saraiva, 2016. p. 71-75.

MOLINARO, Carlos Alberto; MILHORANZA, Mariângela Guerreiro. Tempo, Direito e Processo - Brevíssimas Reflexões. Revista Páginas de Direito, Porto Alegre, ano 13, $\mathrm{n}^{\circ}$ 1075, 03 de setembro de 2013. Disponível em: <http://www.tex.pro.br/home/artigos/173artigos-jul-2013/4752-tempo-direito-e-processo-brevissimas-reflexoes> Acesso em: 07 de abril de 2016

NEVES, Daniel Amorim Assumpção. Manual de direito processual civil. 8 ed. Salvador : Ed. Juspodivm, 2016.

NEVES, Iedo Batista. Vocabulário prático de tecnologia jurídica e de brocardos latinos. 5 ed. rev. e ampl. Rio de Janeiro: Fase, 1992.

NOGUEIRA. Cláudia Albagli. O Novo Código de Processo Civil e o sistema de precedentes judiciais: pensando um paradigma discursivo da decisão judicial. Revista Brasileira de direto Processual - RBD PRO, Belo Horizonte. ano 22, n. 88. p.185-210, out./dez., 2014.

OLIVEIRA, Carlos Alberto Alvaro de; MITIDIERO, Daniel. Curso de processo civil: teoria geral do processo civil e parte geral do direito processual civil. São Paulo: Atlas, 2010. 1v.

ORDEM DOS ADVOGADOS DO BRASIL. Ofício 706/2016 - OAB. Brasília, DF.10 de maio de 2016. Disponível em: 〈http://s.conjur.com.br/dl/prazo-cpc-oab-cnj.pdf> Acesso em: 26 de maio de 2016.

Ofício 1178/2016 - OAB. Brasília, DF, 10 de maio de 2016. Disponível em: < http://s.oab.org.br/arquivos/2016/08/oficio-revisao-de-enunciadosdias-uteis-003.pdf > Acesso em: 06 de novembro de 2016.

PEIXOTO, Ulisses Vieira Moreira. Os prazos no novo código de processo civil. $1^{\mathrm{a}}$ ed. Campo Grande : Contemplar, 2016.

RIO DE JANEIRO. Tribunal de Justiça. Enunciado n ${ }^{\circ}$ 12/2016 da Comissão Judiciária de Articulação dos Juizados Especiais - COJES. "PRAZOS - FORMA DE CONTAGEM. Os prazos processuais em sede de Juizados Especiais Cíveis são contados em dias corridos, inaplicável o artigo 219 do Código de Processo Civil de 2015.”. Disponível em <http://www.tjrj.jus.br/documents/10136/18972/aviso-conjunto-tj-cojes-15-2016.pdf> Acesso em: 06 de novembro de 2016. 
RIO GRANDE DO SUL. Tribunal de Justiça. Décima Câmara Cível. Agravo de Instrumento n. 70008695660 - Comarca de Santa Cruz do Sul. Relator: Jorge Alberto Schreiner Pestana, 06 mai. 2004. Diário da Justiça, Porto Alegre, 11 mai. 2004.

RIO GRANDE DO SUL. Tribunal de Justiça. Décima Câmara Cível. Apelação Cível n. 70017285024 - Comarca de Canoas. Relator: Luiz Ary Vessini de Lima, 22 mar. 2007. Diário da Justiça, Porto Alegre, 10 de abril de 2007.

RIO GRANDE DO SUL. Tribunal de Justiça. Ofício circular 054/2016 CGJ TJRS. Porto Alegre, RS, 22 de abril de 2016. Disponível em:

<http://www.tjrs.jus.br/site/imprensa/destaques/doc/2016/OFICIO_CIRCULAR_054_2016_C GJ.pdf> Acesso em: 26 de maio de 2016.

RIO GRANDE DO SUL. Tribunal de Justiça. Segunda Turma Recursal Cível. Mandado de Segurança $n^{\circ} 71006091029$ - Comarca de São Leopoldo. Relator: Roberto Behrensdorf Gomes da Silva, 25 mai. 2016. Diário da Justiça, Porto Alegre, 30 mai. 2016.

RIO GRANDE DO SUL. Tribunal de Justiça. Vigésima Câmara Cível. Agravo de Instrumento $\mathrm{n}^{\circ} 70048250807$ - Comarca de Porto Alegre. Relator: Glênio José Wasserstein Hekman, 09 abr. 2012. Diário da Justiça, Porto Alegre, 13 abr. 2012.

SOUZA, Marcel Brasil. Cômputo dos prazos. In: CRUZ E TUCCI, José Rogério. Coleção repercussões do Novo CPC: Advocacia. Coordenador José Rogério Cruz e Tucci. Salvador : Juspodivm, 2015. 2 v. p. 34-40.

TARTUCE, Flávio. Manual de direito civil. 6. ed. rev., atual. e ampl. - Rio de Janeiro: Forense; São Paulo: MÉTODO, 2016.

TEIXEIRA FILHO, Manoel Antônio. Curso de direito processual do trabalho. São Paulo : Ltr, 2009. $1 \mathrm{v}$.

THEODORO JÚNIOR, Humberto. Curso de Direito Processual Civil - Teoria geral do direito processual civil e processo de conhecimento. Rio de Janeiro: Forense, 2011.

TOCANTINS. Tribunal de Justiça. Juizados Especiais Cíveis seguirão prazos processuais do novo CPC. Disponível em <http://www.tjto.jus.br/index.php/listagem-noticias/4059juizados-especiais-civeis-seguirao-prazos-processuais-do-novo-cpc $>$ Acesso em: 06 de novembro de 2016.

TUPINAMBÁ, Carolina. O processo do trabalho e os novos prazos processuais do CPC/2015. In: BRANDÃO, Cláudio; MALLET, Estêvão. Coleção repercussões do novo CPC,

Processo do Trabalho. Coordenadores Cláudio Brandão e Estêvão Mallet. $2^{\circ}$ ed. rev. e atual. Salvador: Juspodivm, 2016. 4 v . p. 247-283.

WAMBIER, Luiz Rodrigues. Curso avançado de processo civil: teoria geral do processo e processo de conhecimento. 11. ed. rev e ampl. São Paulo : Revista dos Tribunais, 2010. 1 v. 
Curso avançado de processo civil: teoria geral do processo e processo de conhecimento. 15. ed. rev e ampl. São Paulo : Revista dos Tribunais, 2015. 1 v.

WAMBIER, Teresa Arruda Alvim Wambier. et. al. Primeiros comentários ao novo código de processo civil: artigo por artigo. Coordenação Teresa Arruda Alvim Wambier... [et al.]. 1 ed. São Paulo : Revista dos Tribunais, 2015.

ZARIF, Claudio Cintra. Dos prazos. In: ALVIM, Angélica Arruda. et. al. Comentários ao código de processo civil. Coordenadores Angélica Arruda Alvim... [et. al.] 1 ed. São Paulo : Saraiva, 2016. p. 292-300. 